\title{
„Národopisné oddělení
}

\section{jest chloubou našeho Muzea“. Cesty muzejního národopisu v letech 1918-1938}

\author{
Klára Woitschová
}

DOI: 10.21104/CL.2018.3.02

\begin{abstract}
"The Ethnographic Department is the Pride of our Museum." The Paths of Museum Ethnography in 1918-1938
\end{abstract}

Abstract The study, based on original and unused archive materials, aims to describe and analyze the development of the ethnographic department of the National Museum in years 1918-1938, in the context of contemporary ethnographic science and museology transformations as well as socio-political conditions. A separate ethnographic department of the National Museum was established in 1922, when the museum's existing ethnographic collection was merged with the treasures of the Czechoslavic Ethnographic Museum. This unification was a manifestation of the centralist tendencies of Czech interwar museum management. Another such tendency - strong political influences on cultural institutions - was represented by an unsuccessful attempt to further unite thus created entity with the collections of the Czechoslovak Agricultural Museum. In context of the entire Museum's development, some interesting features of the department's development can also be mentioned: under the leadership of Václav Fabian and Drahomíra Stránská, later one of the key figures of Czech interwar ethnography, the department became a pioneer of short-term exhibitions, and a picture archive was an integral part of the ethnographic collection from the very beginning. Certain scientific projects in the department were important in terms of the development of ethnography (an attempt to establish an open-air folk museum), but they also had a significant political aspect (moving the Greek-Catholic church from the Carpatho-Ruthenian town Medvedovce to the Kinský Garden complex).

Key words National Museum, Drahomíra Stránská, Václav Fabian, History of Ethnography, History of Museology.

Text vznikl v rámci projektu financovaného Grantovou agenturou ČR „Národní muzeum v éře Československa“" (GA16-02022S).

Contact PhDr. Klára Woitschová, Ph.D., Archiv Národního muzea, Na Zátorách 6, 17000 Praha 7, Czech Republic; e-mail: woitschovaklara@seznam.cz.

Jak citovat / How to cite Woitschová, Klára. (2018). „Národopisné oddělení jest chloubou našeho Muzea."

Cesty muzejního národopisu v letech 1918-1938. Český lid 105, 285-324.

doi:http://dx.doi.org/10.21104/CL.2018.3.02 


\section{Úvod}

Dějiny národopisu (později etnografie, etnologie) jako vlastenecko-sběratelské a později již přísně vědecké disciplíny byly na našem území od samého počátku nezřídka velmi úzce spjaty s rozvojem výstavnictví a muzeí. V českém i moravském prostředí i jazykově (česky a německy) odlišných národních společenstvech hrála muzea až do vzniku specializovaných univerzitních pracovišt' a profesních spolků mnohdy naprosto klíčovou úlohu v regionálních i zemských kontextech a např́íklad o vlivu Národopisné výstavy českoslovanské na zrod moderního českého národopisu není nejmenších pochyb (Horák 1933; Jungbauer 1937; Brouček 1979; Lozoviuk 2008; Altman 2005). Dějiny muzeí, muzeologie a národopisu proto tvořily a dodnes tvoří úzce provázaný celek (viz řada statí v práci Woitsch - Jůnová Macková 2016). Dějiny etnografických muzejních kolekcí a s nimi svázaných pracovišt' lze přitom studovat $\mathrm{z}$ mnoha úhlů pohledu a sledovat je různou optikou, počínaje zájmem o výrazné osobnosti přes dějiny jednotlivých sbírek až třeba k pohledu spíše administrativně organizačnímu, který se zabývá sledováním vývoje konkrétních oddělení.

Tato studie se pokouší zohlednit všechny zmíněné aspekty, a to na bohatém empirickém a doposud minimálně vytěženém materiálu, který se váže k národopisnému oddělení Národního muzea v Praze. Cesta k osamostatnění národopisu v rámci Národního muzea byla poměrně dlouhá. Svébytná sbírka předmětů dokumentujících „život lidu“ byla etablována až koncem 19. století, či dokonce z hlediska administrativního až v období první československé republiky. Když už však bylo ustaveno, vyvíjelo se národopisné oddělení tak dynamicky, že si v roce 1923 vysloužilo od jednatele Společnosti Národního muzea v jeho výroční zprávě dokonce epiteton uvedený v titulu tohoto článku. Text se soustř̌edí na období první československé republiky, kdy emancipace národopisného oddělení Národního muzea vrcholila a kdy muzejní etnografie, ostatně stejně jako celé Národní muzeum, čelila mnoha významným impulsům a výzvám. Cílem textu je zevrubná deskripce vývoje národopisného oddělení naší přední muzejní instituce v letech 1918-1938 a interpretace a zařazení tohoto vývoje do širších kontextů, kdy v rámci společensko-politického vývoje i v kontextu dějin celého Muzea bude věnována pozornost zejména níže uvedeným vybraným aspektům existence tohoto oddělení. Přihlížíme přitom i k vývoji národopisné vědy jako celku, a to s vědomím toho, že příslušné oddělení Národního muzea bylo v období první československé republiky jedním v nemnoha institucionálně pevně ukotvených pracovišt stále ještě se formující disciplíny. $Z$ hlediska tvorby oborové teorie a metodologie, prováděných sběrů a výzkumů či publikační činnosti proto, ač poněkud pozapomenuto, národopisné oddělení Národního muzea nepochybně stojí hned vedle klíčové profesní organizace - tedy Národopisné společnosti (Smrčka 2011), Státního ústavu pro lidovou píseň (Tyllner - Suchomelová - Thořová 
2005), národopisných seminářů pražské německé univerzity (Lozoviuk 2006), Chotkovy národopisné katedry na univerzitě v Bratislavě (Ducháček 2017) či Lidovědného oddělení Moravského zemského muzea v Brně.

Při studiu vývoje pracoviště budeme v první ŕadě reflektovat soudobé trendy v muzeologii směřující tehdy - i na základě „politické objednávky“- jednoznačně k centralizaci československého muzejnictví. Tento fenomén se v dějinách národopisného oddělení projevil v poměrech Národního muzea snad nejvýrazněji - nejprve stál za největším rozkvětem národopisných sbírek, nicméně v dalším vývoji mohl znamenat též jejich zánik, respektive převedení do jiné instituce. V této souvislosti je tedy detailně sledován administrativně organizační vývoj oddělení a také některé aspekty jeho každodenního provozu ve smíchovském Letohrádku Kinských, nebot národopisná sbírka byla první, která opustila bezpečné útočiště muzejní budovy na Václavském náměstí a existovala se všemi výhodami i nevýhodami detašovaného pracoviště.

Pouze v hrubých rysech a obecných tendencích je možno sledovat budování národopisné sbírky, a to především $v$ těch momentech, kdy se v něm projevují rysy pro muzejní praxi té doby zcela charakteristické, či naopak zcela netypické. Konkréta tedy ponecháváme ve většině případů záměrně stranou, nikoli pro jejich odbornou nezajímavost, ale vzhledem k obecnějšímu zaměření této studie. Podrobnější pozornost je ovšem věnována využívání a prezentování sbírky, protože se ukazuje, že některé výstavní projekty (zejména ty pořádané ve 30 . letech minulého století), které byly v Letohrádku realizovány, svou organizací a rozsahem přesahovaly v mnoha ohledech muzejní standard té doby.

Meziválečné období také přineslo pro muzejní národopis několik ambiciózních vědeckých projektů, které byt se nakonec uskutečnily pouze částečně či vůbec, ukazují na vysokou úroveň tohoto oboru v Národním muzeu. Odrážejí jednak přelomové (a ve výsledku úspěšné) úsilí vymanit vnímání a studium lidové kultury z omezeného obzoru sběratelských, respektive uměnovědných či výhradně estetických hledisek a vybudovat z jejího studia skutečný vědecký obor, a to jak napojením na další oborově příbuzné instituce budované u nás (Národopisná společnost, univerzitní studia), tak i reflexí různých zahraničních aktivit.

Ve sledovaném období působily $\mathrm{v}$ tomto oddělení také některé zajímavé osobnosti, jimž bude také věnována pozornost. Tváŕí muzejního národopisu byla pochopitelně především Drahomíra Stránská, nicméně zde působili i jiní, jejichž stopa je v Muzeu dodnes zřetelná. Navíc můžeme v některých př́padech sledovat personální záležitosti i v obecnější rovině, nebot' obsazování míst bylo v Muzeu obecně dosti komplikované. 


\section{Prameny a literatura}

Hlavním pramenem pro dějiny Národního muzea (dále také NM) je jeho písemná registratura, která je uložena v Archivu NM. Jedná se o mimořádně rozsáhlý soubor písemností a pro předmětné období a stanovené téma přicházejí v úvahu zejména tři její části. V první řadě všeobecné písemnosti centrální muzejní správy, které odrážejí především všeobecný vývoj instituce a jejího ředitelství. Zobrazuje v celé šiŕi například styky s nadřízenými úřady (v této době zemské úrrady a ministerstvo školství a národní osvěty), finanční záležitosti, agendu plánů a výkazů, personální problematiku, všeobecnou korespondenci (zejména se zahraničím) atd. Až do roku 1928 je registratura uspořádána chronologicky, písemnosti jsou uloženy v pořadí podle toho, jaké číslo jednací jim bylo přiděleno. Po roce 1928 se struktura uložení mění a byl zaveden systém signatur, v němž krom oddílů pro všeobecnou správu a personálie byly shromážděny písemnosti jednoho oddělení vždy pospolu. Sledování vývoje jednotlivých oddělení je po této změně jednodušší. ${ }^{1}$

Zároveň byly vedeny i registratury jednotlivých částí Národního muzea, v nichž se detailněji odráží jejich každodenní agenda. Do jisté míry jsou tyto dílčí registratury duplicitní té centrální, jejich studium však nelze přesto pominout právě vzhledem k často podrobnějšímu líčení všech událostí a také vzhledem k některým deperditům v písemnostech ústřední povahy. ${ }^{2}$ Třetím dílčím fondem registratury jsou pak písemnosti Společnosti Národního muzea, která po většinu období vymezeného pro tuto studii byla hlavní představitelkou instituce a ovlivňovala všechny myslitelné aspekty jejího chodu. Pro účely tohoto textu byly využity protokoly z jednání správního výboru Společnosti z let 1922-1935. 'Zcela pominout nelze ani osobní fond Drahomíry Stránské, avšak $\mathrm{z}$ něj bylo využito jen několika málo tištěných jednotlivin vzhledem $\mathrm{k}$ tomu, že byl dosti detailně vytěžen již předcházejícími badatelkami při tvorbě monografie věnované jejímu životu a dílu (Mevaldová - Tauberová 2011). ${ }^{4}$

Dosavadní literatura věnovaná vývoji muzejní etnografie není příliš bohatá. Obecně jsou novodobé dějiny Národního muzea po roce 1918 reflektovány pouze několika málo tituly, z nichž starší jsou poměrně speciálně zaměřené (Saturník 1924, Švehla 1946), novější pak lze bez překážek využívat k získání všeobecného přehledu o dění v Muzeu (Sklenář 2001, Sklenář 2007). Je možno

1 Archiv Národního muzea (dále ANM), fond Národní muzeum

(1818-1960) (dále RNM), částečně zpracováno, 48 bm.

2 ANM, fond RNM-HM4 - Národopisné oddělení

(1826-2000) (dále RNM-HM4), nezpracováno, 6,63bm.

3 ANM, fond RNM - Společnost Národního muzea (1854-1993) (dále RNM-SNM), částečně zpracováno, 3,89 bm (protokoly a zápisy ze schůzí jsou uloženy v kartonu 1).

4 ANM, fond Stránská Drahomíra (1899-1964), 7,15bm, zpracováno.

Bláhová Ivana - Pecharová Emilie - Šubrtová Alena: Drahomíra Stránská (1899-1964). Prozatímní inventární seznam, Praha 1970. 
se obrátit k specifickým a spíše dílčím sekundárním zdrojům. Prvně jmenované představují jednatelské zprávy Národního muzea. V období, o němž pojednává tento text, byly přednášeny na valných zasedáních Společnosti NM a poté vydávány tiskem. Jedná se sice pouze o stručné sumáře každoročního dění v instituci, na druhou stranu je však zřejmé, že událostem v nich zmíněných přikládala sama instituce významné postavení. Zde jen podotkněme, že záležitosti národopisného oddělení se v těchto zprávách objevovaly poměrně pravidelně.

Řada dílčích studií počíná souhrnem dějin národopisného oddělení v letech 1818-1948 z pera Drahomíry Stránské, který byl publikován ve výročním sborníku pod redakcí tehdejšího odborného ředitele NM Gustava Skalského (Stránská 1949: 119-136). Další texty reflektují vývoj muzejní etnografie samostatně (Langhammerová 2015) či jako jedné ze součástí společenskovědních oborů pěstovaných v muzeu (Burian 1968), z osobností si vysloužila pozornost zatím především Drahomíra Stránská a některé její významné projekty (Mevaldová - Tauberová 2011, Mevaldová 2015).

\section{Administrativní vývoj}

V roce 1892 došlo k významné reorganizaci muzejních sbírek. Od knihovny byla oddělena sbírka prehistorické archeologie a historické archeologie, jejíž součástí byla tehdy ještě nepřiliš četná etnografika domácí i cizí provenience. Národopisné materiály měly tvořit v rámci historicko-archeologické sbírky samostatné oddělení, nicméně správce obou byl společný. Byl jím od 1. května 1892 Jan Koula (ke starším dějinám sbírky srv. velmi podrobně Sklenář 2014).

Paralelně byly však budovány s daleko vyšší intenzitou národopisné sbírky v jiné instituci, jíž bylo Národopisné muzeum českoslovanské. Vzniklo v roce 1896 na základech Národopisné výstavy z roku 1895. Jeho organizace byla v základních rysech obdobná jako organizace NM: jednalo se o instituci v majetku soukromé společnosti (Národopisné společnosti českoslovanské), která měla na starosti jak jeho odborný program, budování sbírek, tak také zajištění správy a financování muzea. A provázely je i stejné problémy, nedostatek místa a obtíže s financováním (Šenfeldová 2015).

Těžkou zkoušku představovala pro obě „konkurenční“ soukromé muzejní společnosti první světová válka. Zatímco Národní muzeum se v poslední chvíli zachránilo díky apelu uveřejněnému na stránkách novin a svou neblahou finanční situaci nakonec vylepšilo, Národopisnému muzeu zasadila válečná léta nezhojitelné ekonomické rány. Jeho činnost byla prakticky ochromena. Nebyly peníze ani na rozmnožování sbírek, ani na jejich správu. Řešení, které se nabízelo, bylo odevzdání ohrožených sbírek do správy země České, realizované ve skutečnosti přivtělením muzejních fondů i zaměstnanců k národopisné sbírce Národního muzea. 
Návrh přednesený Radou Společnosti Národopisného musea českoslovanského zemskému správnímu výboru spočíval v následujícím (celý text srv. v Př́loze 1): Společnost daruje veškeré své sbírky zemi České, pokud budou následně přivtěleny k národopisným sbírkám Národního muzea a zůstanou uloženy v Letohrádku Kinských na Smíchově (č. p. 98). Další podmínkou bylo to, že dosavadní zaměstnanci budou převzati (včetně započtení služebních let) do zemských služeb a jejich platy tedy budou financovány zemí. ${ }^{5}$ Národopisná společnost si dále vymínila v Letohrádku dvě místnosti pro vlastní využití a členové Společnosti měli mít jistá privilegia při využívání knihovny Národopisné společnosti (později byly tyto výhody rozšířeny ještě na možnost využívat reprodukční techniku národopisného oddělení), jejíž činnost měla i po předání sbírek dále pokračovat. ${ }^{6}$

Nabídka Společnosti byla nakonec v roce 1922 využita a stanovené podmínky byly v plném rozsahu akceptovány, byt jejich realizace byla v poměrech Národního muzea nakonec dosti složitá, především co se týkalo získání financí na realizaci naplánovaných změn. Postavení národopisu měl ve výboru Společnosti Národního muzea hájit nově kooptovaný člen, jímž se stal prof. Jan Jakubec (tehdejší předseda Národopisné společnosti). Ve skutečnosti však bylo příznivců národopisu ve vedení Muzea více, nebot ve výboru již před spojením obou institucí zasedal i Lubor Niederle, Jiří Polívka a Augustin Žalud.

V jednatelské zprávě za rok 1922 tedy mohl tehdejší jednatel Společnosti NM spokojeně konstatovat, že: „Sbírky Národopisného Musea, které přijala ve svůj majetek země jako dar Společnosti Národopisného Musea Českoslovanského, staly se součástí národopisného oddělení našeho ústavu, byly s ním sloučeny v musejní budově v Kinského zahradě a jsou nyní pod správou ředitele Dra V. Fabiana účelně a jednotně instalovány. Společnost Národopisného Musea... zůstala ovšem zachována a svou činností stala se účinnou oporou pro toto oddělení. Tímto sloučením stal se významný krok v akci pro účelné soustředění musejního materiálu, dnes namnoze ještě roztř́štěného...“.7 K protokolárnímu převzetí došlo 8. května $1922 .{ }^{8}$ Na tomto místě ještě podotkněme, že ze strany Národního muzea byl podniknut při příležitosti splynutí obou institucí také pokus o spojení časopisů, tedy Časopisu

5 To znamenalo, že se jim dostane stejného statusu jako ostatním zaměstnancům Národního muzea, kteří byli převzati do zemských služeb již k 1. 1. 1918 a jejich mzdu vyplácel zemský úřad, byt' muzejní sbírky byly až do roku 1935 stále v majetku Společnosti Národního muzea. Toto uspořádání personálních záležitostí bylo na jedné straně pro zaměstnance výhodné, na straně druhé ale mohlo skrývat některá úskalí, jak bude podrobněji ukázáno v oddílu o personálních záležitostech. ANM, RNM, k. 91, spis č. 9. Národopisné museum na Smíchově. Rada Společnosti Národopisného muzea Zemskému správnímu výboru (Příloha 1).

7 Jednatelská zpráva Národního Musea za rok 1922. Praha 1923.

8 ANM, RNM, k. 91, č. j. 384. Protokol o odevzdání národopisných sbírek Národopisného musea českoslovanského do majetku zemského a do správy Národního musea v Praze. 
Národního muzea a Národopisného věstníku českoslovanského (cílem bylo především zeštíhlení agendy Národopisné společnosti), ale ke spojení nakonec nedošlo. ${ }^{9}$

Národopisné oddělení se tímto krokem dočkalo po všech stánkách dosud nevídaného rozmachu. Zmnohonásobilo své sbírky, výrazně posílilo i své personální obsazení a definitivně se v muzejní správní struktuře osamostatnilo pod vedením Václava Fabiana, který do té doby pracoval jako odborný pracovník oddělení historické archeologie. $\mathrm{V}$ této podobě pak fungovalo bez větších proměn několik málo následujících let.

V roce 1926 se ovšem přiblížila další zásadní reforma muzejní etnografie, která měla podle původního plánu skončit jejím naprostým odloučením od Národního muzea. V této chvíli se projevily dvě výrazné tendence prvorepublikového muzejnictví. První z nich směřovala k jeho centralizaci. Podílelo se na ní aktivně i Národní muzeum jako jedna z předních muzejních institucí nového státu, když svolilo k převzetí národopisných sbírek, jak o tom byla řeč výše, a například když se pokoušelo (byt' opravdu jen nesměle) o převzetí sbírek Průmyslového muzea či později (naopak velmi usilovně) Náprstkova muzea.

V tuto chvíli se však v podobě Československého zemědělského muzea objevil v oblasti národopisu silnější soupeř, jehož nebylo možno pominout a ještě méně snadné bylo jej porazit. Za autoritou Zemědělského muzea (dále také ZM) v této oblasti stál nepochybně výrazný politický vliv Republikánské strany zemědělského a malorolnického lidu, tedy tzv. agrární strany. Napojení kulturních institucí na politické strany je pak druhou okolností, která ovlivňovala podobu muzejnictví té doby, v př́ípadě národopisu můžeme dokonce mluvit o vlivu právě agrárníků na vývoj oboru jako takového (Ducháček 2016: 61-62). Zatímco ve správním výboru Společnosti Národního muzea dominovali národní demokraté, zemědělské muzejnictví a s ním blízce související národopisné sbírky spadaly z pochopitelných důvodů do sféry vlivu agrární strany.

Kde se přesně zrodila myšlenka na propojení obou tehdy nejvýznamnějších sbírek mapujících život venkovského lidu, není zcela zřejmé. Ze záznamu z jednání výboru Společnosti NM vyplývá, že to bylo z podnětu zemského správního výboru, ${ }^{10}$ avšak lze předpokládat, že v pozadí stály aktivity Zemědělského muzea, které usilovalo o rozšíření svých sbírek a mělo pro tyto aktivity také př́ślušné finanční jištění zprostředkované vlivným agrárním politikem Milanem Hodžou, ministrem školství a zemědělství v několika prvorepublikových vládách. Ve správním výboru zavládlo zděšení. S muzejními sbírkami mělo být manipulováno bez vědomí Společnosti NM! Př́ípadný boj s tímto plánem však byl pro Muzeum předem víceméně prohraný, nebot velká část sbírek (tedy ty původně náležející Národopisnému muzeu) byla depozitem

9 ANM, RNM-SNM, k. 1. Protokol o schůzi správního výboru dne 10. dubna 1922.

10 ANM, RNM-SNM, k. 1. Protokol o schůzi správního výboru dne 23. února 1926. 
zemského majetku a zemský úřad tedy o nich mohl poměrně volně rozhodovat, jen malá část (původní muzejní národopis) skutečně patřila Společnosti NM. Bylo ovšem i tak rozhodnuto, aby se správní výbor „ohradil proti jakémukoliv kulturnímu násilí a odtrhování muzejních sbírek."11 Zároveň nebylo politicky únosné tento podnět ignorovat a představitelé Národního muzea se museli snažit získat alespoň co nejvýhodnější podmínky.

Byla ustavena společná komise se zastoupením všech zúčastněných institucí: Zemědělského muzea (Josef Kazimour), Národní rady československé (Adolf Prokůpek), Národního muzea (Bohumil Němec a Jan Kapras) a zemského výboru (František Hoch). Tato komise vypracovala po složitých jednáních návrh smlouvy (Příloha 2 tohoto textu), který měly schválit vrcholné správní orgány obou muzeí. Paralelně probíhala také zcela neformální jednání jednatelů obou Společností (tedy NM i ZM), profesorů B. Němce a J. Kazimoura, jejichž obsah se však samozřejmě v oficiálních pramenech neodráží.

Hlavním principem mělo být sjednocení veškerých etnografických sbírek v rámci jediné instituce - Zemědělského muzea. Tento požadavek nebyl nelogický. Vždyt jak Národopisné muzeum, Zemědělské muzeum, tak i národopisné oddělení Národního muzea stavěly své sbírky na základech předmětů shromážděných při příležitosti obou velkých výstav konce 19. století, tedy Jubilejní zemské výstavy v roce 1891 a především Národopisné výstavy konané v roce 1895. Mělo tedy fakticky jít o jejich znovusjednocení (celou kauzu z pohledu Zemědělského muzea srv. nejnověji Steinová 2013: 13nn).

Náklady na správu, udržování budovy i sbírek mělo hradit Zemědělské muzeum, jím zakoupené předměty měly pak přirozeně být jeho vlastnictvím. Původní struktura sbírek však měla být zachována formou oddělených evidencí, tedy zvláštní řada čísel pro předměty v zemském vlastnictví (tj. především sbírky původního Národopisného muzea), v majetku Společnosti NM (tedy původní oddělení etnografie) a třetí řadu měly představovat sbírky Československého zemědělského muzea. Správa sbírek měla být společná (zvláštní čtyřčlenná komise). Co se dotýkalo prostorového uspořádání, tak Zemědělskému muzeu bylo přislíbeno postavení účelové novostavby, uprázdněný Letohrádek Kinských na Smíchově (a také Zemědělským muzeem uvolněná tzv. Švýcárna v blízkosti Letohrádku) měly připadnout Národnímu muzeu k jeho využití.

Hlasování v Zemědělském muzeu proběhlo, nikoli překvapivě, rychle a bez problémů. Jeho hlavní reprezentant, valná hromada Československého Zemědělského Musea, schválil bez větších potíží předmětnou smlouvu již 15. dubna 1926. ${ }^{12}$ Klíčové hlasování o smlouvě v Národním muzeu bylo stanoveno na 15. prosince téhož roku, na kdy bylo svoláno mimořádné valné shromáždění Společnosti NM, které jediné bylo oprávněno takto důležitý

12 ANM, RNM, k. 103. Zpráva Čs. zem. musea Národnímu museu ze dne 19. 11. 1926. 
dokument schválit. Zasedání vedl viceprezident Společnosti Bohumil Němec, který smlouvu představil (záměrně neříkáme obhajoval, protože strategie byla jasně dána: celý projekt na valném zasedání pouze bez emocí prezentovat) a vedl následnou debatu, v níž však zejména zástupce ministerstva školství a národní osvěty vystupoval ostře proti projektu spojení. Tímto zástupcem byl Zdeněk Wirth, který (možná poněkud překvapivě) hájil stanovisko, že „na musejnictví nesluší ... pohlížeti politicky; politisování kultuře škodí.“13 První hlasování dopadlo velmi těsně. Z 25 hlasů bylo 13 pro schválení smlouvy, 12 pro její zamítnutí. Většina se Němcovi zdála v tak zásadní záležitosti nepřesvědčivá, navíc se vyskytly i hlasy o zmatečnosti a neregulérnosti proběhlého hlasování. Hlasovalo se proto znovu a tentokrát byl výsledek opačný - 12 hlasů bylo pro smlouvu, 13 proti. Předsedající nakonec prohlásil, že účast na shromáždění je př́liš malá a že se hlasování bude opakovat na příští řádné valné hromadě. ${ }^{14}$

Zmíněné hlasování s rozpačitým výsledkem jasně naznačovalo, že tento projekt není v Muzeu přiliš vítaný. Na misky vah připadaly samozřejmě argumenty obou stran. Lákavou nabídkou pro Muzeum jistě byly přísliby nových volných prostor. A to jak v Letohrádku Kinských, tak ve druhé budově v areálu na Smíchově, v tzv. Švýcárně, kde dosud sídlilo Zemědělské muzeum. Zájemců o tyto prostory bylo v Muzeu hodně, nejvážnějším kandidátem bylo ovšem nově zř́izené divadelní oddělení (nazývané někdy i Divadelní muzeum). Snad ještě lákavější byl příslib, že v těsné blízkosti novostavby Zemědělského muzea budou rezervovány pozemky pro budoucí stavbu pro přírodovědné sbírky Národního muzea. To by znamenalo naplnění mnohaletých plánů a tužeb muzejních př́rodovědců. Přenechání části muzejních sbírek jiné instituci však bylo nakonec prŕliš hořkou pilulkou a muzejní představitelé je, diplomaticky řečeno, nepodporovali, ve skutečnosti však spíše systematicky bojkotovali.

I přesto, že Bohumil Němec několikrát neoficiálně mluvil o celé věci s profesorem Kazimourem a ten nakonec prohlásil, aniž uvedl konkrétní důvody, že celá věc je passé a Zemědělské muzeum na sbírky Národního muzea již nereflektuje, ${ }^{15}$ bylo oficiálně stanoveno datum převzetí sbírek náležejících zemi na 27. ř́́jen 1928 v Letohrádku Kinských.

Přítomen byl jednatel Muzea Karel Domin, dva zástupci Zemědělského muzea (Antonín Mach a František Šach) a tři představitelé zemského správního výboru (Václav Fabian, Antonín Morávek a zemský tajemník Vladimír Wait). Jednatel Národního muzea Karel Domin přišel dobře připraven a vybaven nepřekročitelnými argumenty, které plynuly z nekonzistentnosti postupu zemského úřadu a skutečných nedostatků, jež plán na spojení měl. Dominovo

13 ANM, RNM, k. 103. List jednatele Domina Zemskému správnímu výboru ze dne 11. 2. 1927 a ANM, RNM-SNM, Protokol o schůzi správního výboru NM ze dne 10. listopadu 1926. 
prohlášení bylo založeno na tvrzení, že 1) národopisné sbírky jsou z rozhodnutí zemského výboru z roku 1922 svěřeny do správy Společnosti Národního muzea, tudíž pouze ona sama může rozhodnout o jejich odloučení, což se dosud nestalo, 2) zemský úřad může rozhodnout pouze o sbírkách, které spadají bezprostředně do správy země, nicméně vzhledem k tomu, že jsou instalačně i v katalozích nedílně spojeny s původními sbírkami Národního muzea patřícími Společnosti NM, nelze předání uskutečnit, dokud nebudou oba celky administrativně odděleny (jen připomeňme, že ono administrativní splynutí se stalo na základě příkazu zemského úřadu). Ani další body rozkladu nebylo možno přejít bez dalšího, nebot' hrozilo, že při důsledné aplikaci smlouvy by se národopisné muzejní sbírky mohly ocitnout bez př́istř̌eší i bez svých správců. „Poněvadž vzhledem k tomu, co uvedeno, nebylo možno odevzdání sbírek provésti, bylo jednání skončeno...“, jak uvádí v závěru protokol a konstatuje, že o celé věci se bude ještě dále jednat. ${ }^{16} \mathrm{~K}$ dalšímu kolu jednání však nakonec již nedošlo a celá záležitost usnula. Jediným výsledkem tak nakonec byly pouze drobné přesuny sbírkových předmětů mezi oběma muzei.

Ještě jednou, v letech 1931 a 1932, se několikrát objevily na stránkách denního tisku zprávy o chystané centralizační akci zaměřené na národopisná muzea, jejímž cílem údajně bylo zřízení nového muzea všeobecného národopisu. Jednalo se o aktivitu „shora“, zaštítěnou ministerstvem školství a národní osvěty, která byla čistě administrativní a nebyla založena na žádných sbírkách, již existující muzea tedy na ni hleděla s krajním podezřením. ${ }^{17}$

Je možné, že tento ruch souvisel také s chystaným (a posléze realizovaným) pozemštěním sbírek Náprstkova muzea (založeno 1862, sbírka českého národopisného materiálu pod názvem Práce našich matek zde začala být budována od roku 1877 a v pojednávané době již byla poměrně rozsáhlá), které měly být podle očekávání Národního muzea svěřeny do jeho správy, či alespoň bylo pravidelně spojení obou institucí pod hlavičkou Národního muzea anoncováno v jednatelských zprávách NM (již od roku 1928). Vztah obou muzeí však zůstal v dané chvíli volný, respektive Náprstkovo muzeum bylo dáno nepř́imo pod správu Národního muzea a mělo být spravováno triumvirátem složeným z administrativního ředitele Antonína Zemka, správce historicko-archeologické sbírky Karla Gutha a ředitele muzejní knihovny Josefa Volfa. Definitivní připojení Náprstkova muzea a spolu s ním i jeho národopisných sbírek ovšem nastalo až k 1. lednu 1943 nařízením správy Protektorátu Čechy a Morava. Následné přesuny sbírek tedy spadají již mimo časové vymezení sledované touto studií. 
Při pozemštění Národního muzea v roce 1935 bylo národopisné oddělení zařazeno vzhledem k povaze svých sbírek mezi tzv. duchovědná oddělení, na jeho fungování to však nemělo žádný vliv, tato úprava muzejních poměrů spíše odrážela jisté dlouhodobé pnutí mezi společenskovědními a přírodovědnými odděleními Národního muzea, které se datovalo již od poloviny 19. století a několikrát hrozilo vyvrcholit osamostatněním obou částí. K tomu však došlo v omezené míře až při organizačních reformách instituce v 60. letech 20. století, kdy se národopisné sbírky staly přirozenou součástí Historického muzea NM. Další administrativní změny se pak již národopisné sbírce a národopisnému oddělení jako takovému až do konce sledovaného období vyhýbaly.

\section{Personálie}

Snad více než v kterémkoli jiném oddělení platilo pro prvorepublikovou sbírku národopisu to, že její charakter utvářela osobnost stojící v čele. První dvě osobnosti vedoucí národopisné oddělení formovaly tuto sbírku prizmatem dějin umění. Zájmy Jana Kouly (1855-1919, Lidová kultura 2007: 118) byly ovšem velmi široké. Na jedné straně byl stavitelem a architektem, kromě mnoha uskutečněných projektů se stal autorem nerealizovaného plánu na dostavbu budovy Národního muzea (která měla být rozšířena o jedno křídlo směrem do Čelakovského sadů), na straně druhé se pak významně angažoval také v ochraně a obnově památek. Při výstavě v roce 1891 spolupracoval s A. Wiehlem na vytvoření České chalupy. Na svěřené sbírky tedy hleděl pohledem estetickým a kunsthistorickým a oceňoval spíše krásu a inspirativnost lidových památek a nesnažil se o jejich prezentaci či interpretaci z pozic tehdy již se formujícího se vědeckého národopisu. Těmto hlediskům zároveň podřizoval i akviziční činnost, což ovlivnilo podobu sbírky prakticky až do dneška.

I jeho následovník Václav Fabian (1877-1931, Lidová kultura 2007: 51) zastával podobné pozice. Prošel historickým a umělecko-historickým studiem a celý svůj profesní život spojil s působením v Národním muzeu, nejprve v historicko-archeologické sbírce, později, jak již bylo zmíněno, se stal přednostou národopisného oddělení. Na tomto postu jej čekala především organizační práce, protože stál před velkým úkolem spojit dva sbírkové celky, vytvořit moderní expozici národopisu (byt stále ještě nikoli z pozic odborného národopisu, ale spíše tak, aby vynikla „dekorativní a barvitá stránka sbírek“, jak později hodnotila jeho práci D. Stránská - Stránská 1949: 132) a zajistit hladký chod nově vzniklého oddělení. Co se týkalo akvizic, za jeho správy bylo získáno mnoho cenných a rozsáhlých sbírek, sotva však bylo možné mluvit o systematické dokumentaci všech aspektů života vesnického lidu. Možná trochu neprávem zůstává ve stínu své nástupkyně Drahomíry Stránské, přestože založil celou řadu aktivit, které ona později tvưrčím způsobem rozvíjela. V první řadě to byly krátkodobé výstavy, ovšem možná nejzáslužnější je jeho budování fotografického archivu jako zcela svébytné součásti sbírkového bohatství 
(Fabian 1925). Z jeho odborných zájmů je možno vyzdvihnout především fundovanou studii o malovaném nábytku (Fabian 1930).

Poslední vedoucí národopisných sbírek ve vymezeném období byla již mnohokráte zmiňovaná Drahomíra Stránská (Mevaldová - Tauberová 2011). Již studia románských a slovanských jazyků a návštěva semináře lidové kultury u prof. Jakubce, stejně jako roční stáž v Jugoslávii předurčila její budoucí směřování ke srovnávacím slovanským studiím. Celý její odborný život se nesl ve znamení publikačních aktivit, působení v předních vědeckých institucích a také se aktivně podílela na organizaci vědeckého a muzejního života. V Muzeu její kariéra začala skutečně od píky. Začínala v roce 1923 jako honorovaná pomocná síla a postupně procházela celou stupnicí služební pragmatiky zemského úřadu počínaje smluvní úřednicí (1928) až k zemské vrchní muzejní komisařce (1945). ${ }^{18}$

Po smrti Václava Fabiana byla pověřena správou národopisného oddělení. Nemohlo tomu být jinak, protože byla jeho jedinou zbývající odbornou pracovnicí. Přesto však cesta $\mathrm{k}$ jejímu plnoprávnému jmenování vedla přes veřejný konkurz, který muzejní správa vypisovala na všechna významnější odborná místa (zejména ovšem na naléhání zemských úřadů, které se obávaly kritiky, pokud by personálie byly řešeny pouze soukromě v Muzeu). Ve výběrové komisi zasedli významní badatelé Lubor Niederle, Jiří Horák, Karel Chotek, odborný rada Merhout (místo Zdeňka Wirtha). Přihlásili se tři uchazeči - Michal Halík z Domažlic, Drahomíra Stránská a Karel Černohorský. Výsledkem „terna“ bylo doporučení Drahomíry Stránské, popř. Karla Černohorského. První ze jmenovaných uchazečů byl tehdy podle komise bez dostatečné praxe. ${ }^{19}$ Dne 26. 2. 1932 tedy byla ustanovena správkyní národopisného oddělení Drahomíra Stránská a na tomto postup pak setrvala až do konce sledovaného období. Její postavení v Muzeu se pak ve válečných letech poněkud zkomplikovalo, a dokonce byla přeřazena do Náprstkova muzea, nicméně to pro účely tohoto textu již ponecháváme stranou.

Podívejme se nyní na personální politiku národopisného oddělení poněkud obecněji. Již na počátku byla řeč o tom, že jednou z podmínek pozemštění Národopisného muzea bylo i to, že zároveň se sbírkami budou nadále zemí Českou financováni i jeho dosavadní zaměstnanci, a tak se také stalo. Z původních zaměstnanců Národního muzea sem nakonec přešel pouze Václav Fabian, který se stal přednostou oddělení. A ačkoli jedním z argumentů spojení bylo, že Národopisné muzeum disponuje naprosto nedostatečným personálem, v poměrech Národního muzea se i s tímto nepočetným osazenstvem stalo jedním z nejlidnatějších oddělení. Nebylo výjimečné, že celé oddělení bylo představováno odborným správcem sbírky a sluhou a laborantem (kteří 
ještě mohli sloužit pro více sbírek společně), národopisné oddělení bezprostředně po spojení mělo však nejen přednostu (Václava Fabiana), kustodku (Vlastu Havelkovou), sekretářku (Věkoslavu Augustovou), dvě administrativní úřednice (Annu Musilovou, Aloisii Hladíkovou), vrátného (Františka Šimečka) a dva dozorce (Josefa Př́íhodu, Leopolda Reichmanna).

Situace tedy vypadala zpočátku poměrně nadějně, nicméně záhy se ukázaly také nevýhody zemské kurately nad obsazováním muzejních postů. Muzeum disponovalo určitým počtem tak zvaně systemizovaných míst, jejichž počet byl závazný (domoci se jejich zvýšení bylo většinou otázkou několikaletého vyjednávání) a která také musela být obsazována podle pevně daných pravidel. V praxi, jak ukazují dosti nepřehledná jednání o osobních záležitostech vedená při zasedáních výboru Společnosti NM, bylo možno některá pravidla mírně „ohnout“, nicméně ve výsledku se obsazení zejména těch lépe placených trvalých míst rovnalo velkému diplomatickému vítězství.

Zápas o obsazování vysokoškolských odborných míst to ukazuje poměrně jasně. Když odcházela v roce 1927 do penze druhá z vysokoškolských sil sledovaného oddělení, Vlasta Havelková (mimochodem první kustodka v českých muzeích, která působila již od jeho vzniku v Národopisném muzeu, Lidová kultura 2007: 68), ${ }^{20}$ na její místo se poměrně hladce posunula právě Drahomíra Stránská. Ale když zemřel Václav Fabian, zůstalo na léta druhé odborné místo ve sbírce neobsazené a veškerá ryze odborná agenda ležela na bedrech nové přednostky.

Než aby byl přijat do Muzea nový pracovník, který byl př́íslušný k národopisnému oddělení svým odborným zaměřením, řešila se tato situace polovičatými opatřeními. Např́íklad byla do Letohrádku přeřazena jedna z pracovnic knihovny, Jiřina Karasová, která měla na svém původním místě na starosti slovanskou knižní sbírku. Zemský úřad byl k takovým přesunům oprávněn, všichni úředníci v zemské službě mu byli v tomto směru k dispozici. Karasová sice byla zdatnou knihovnicí, ba dokonce byla schopna Stránskou zastupovat v čele oddělení po dobu její delší studijní cesty v roce 1933, ${ }^{21}$ těžko to však bylo systémové řešení. Ještě koncem roku 1933 nebylo druhé vysokoškolské místo obsazeno a Národopisná společnost se v této věci dokonce odhodlala k intervenci u muzejního vedení. ${ }^{22}$ Konkurz byl vypsán, nicméně ani jeden z uchazečů zcela nesplňoval představy muzejních představitelů. Uchazeči byli dva: Stanislav F. Svoboda a Bohumil Lifka. Ani jeden nebyl národopiscem, nicméně oba měli v muzejním výboru své zastánce. Jedněm imponovalo, že Svoboda byl alespoň sběratelem národopisu, Lifka byl naopak doporučován jako uměnovědec. Vítězem tohoto zápolení se stal nakonec dr. Svoboda, který později

20 ANM, RNM-HM4, k. 1. Osobní spis Vlasty Havelkové.

21 ANM, RNM, k. 115. Výkaz práce za rok 1933 jiřiny Karasové, 10. 4. 1934.

22 ANM, RNM-SNM, k.1. Zápis o schůzi správního výboru Národního musea, konané dne 17. května 1933 a 27. listopadu 1933. 
také stanul ve vedení oddělení, nicméně i jeho konkurent se později uplatnil v muzejních službách jako významný pracovník Náprstkova muzea.

Při značné obtížnosti domoci se zřízení nového místa však existovaly jisté možnosti, jak opatřit pro oddělení potřebné pracovní síly. Národní muzeum spolupracovalo s Výborem pro pomoc nezaměstnané inteligenci, který i do národopisného oddělení zprostředkoval několik zajímavých pracovních posil. Na jedné straně se jednalo o kancelářské síly, na druhou stranu pak také oddělení poskytlo útočiště několika absolventům studia architektury, kteří pak jezdili po republice a ve službách muzejního národopisu zaměřovali zajímavé či ohrožené lidové stavby a prokázali tak našemu národopisu neocenitelné služby.

Víme, jak vypadal reálný stav věcí, a můžeme jej porovnat s tím, jaká byla ideální představa personálního zabezpečení tohoto oddělení: samozřejmostí byli již zmiňovaní vysokoškolsky vzdělaní úředníci, jedna manipulační síla s knihovnickou kvalifikací, dvě manipulační síly a jeden zřízenec. Navíc ovšem měl být přijat ještě další odborný pracovník, další knihovník, jedna síla odborně vzdělaná ve vyšívání a kreslení vzorů (v podstatě restaurátorka textilu, vzděláním to měla být pokud možno odborná učitelka pro rodinné školy), fotograf (a zároveň filmař) a také truhlár. ${ }^{23}$ Dodejme jen, že vše zůstalo pouze v oblasti plánů a přání a v meziválečném období žádný další pracovník do oddělení nepřibyl.

\section{Z Václavského náměstí na okraj Prahy}

Národopisné oddělení sdílelo, jak již bylo řečeno, zprvu osudy archeologické sbírky a spolu s ní i její prostory. V nové budově na Václavském náměstí byly národopisu původně vyhrazeny tři výstavní sály (č. VII, IX a č. X) a konečně v roce 1922 bylo rozhodnuto o jeho přestěhování do Letohrádku Kinských na Smíchově. Je otázkou, jak toto řešení vnímat.

Odsunem národopisných sbírek a uvolněním dvou sálů byla potěšena především ostatní oddělení a bez velkého přehánění je možno říci, že o uprázdněné sály se strhl „lítý“ boj. Žádostí o přidělení uvolněných prostor přišla na muzejní ředitelství celá řada, jedna úpěnlivější než druhá. Dlužno ovšem říci, že každá do jedné byla naprosto oprávněná, protože prostorová nouze v hlavní muzejní budově byla všudypřítomná, původní optimistické naděje, že prostor budovy otevřené slavnostně v roce 1891 bude stačit na rozvoj muzea dalších 90 let, se ukázaly jako naprosto neopodstatněné. Úspěch nakonec slavila argumentace Karla Gutha, správce sbírky historické archeologie, která nakonec obsadila všechny uvolněné prostory. 


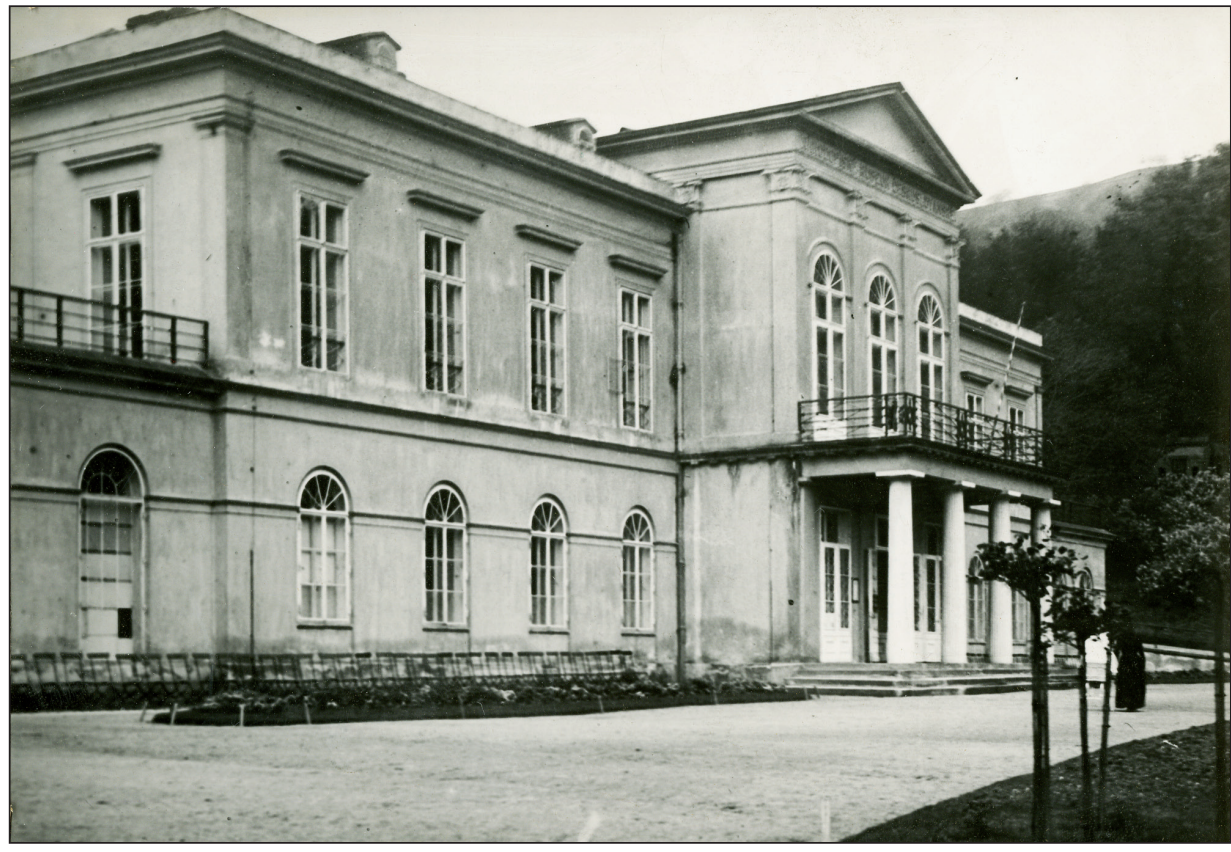

Obr. 1 Letohrádek Kinských na pražském Smíchově. 1903.

ANM, fond OA etnografie, bez čísla.

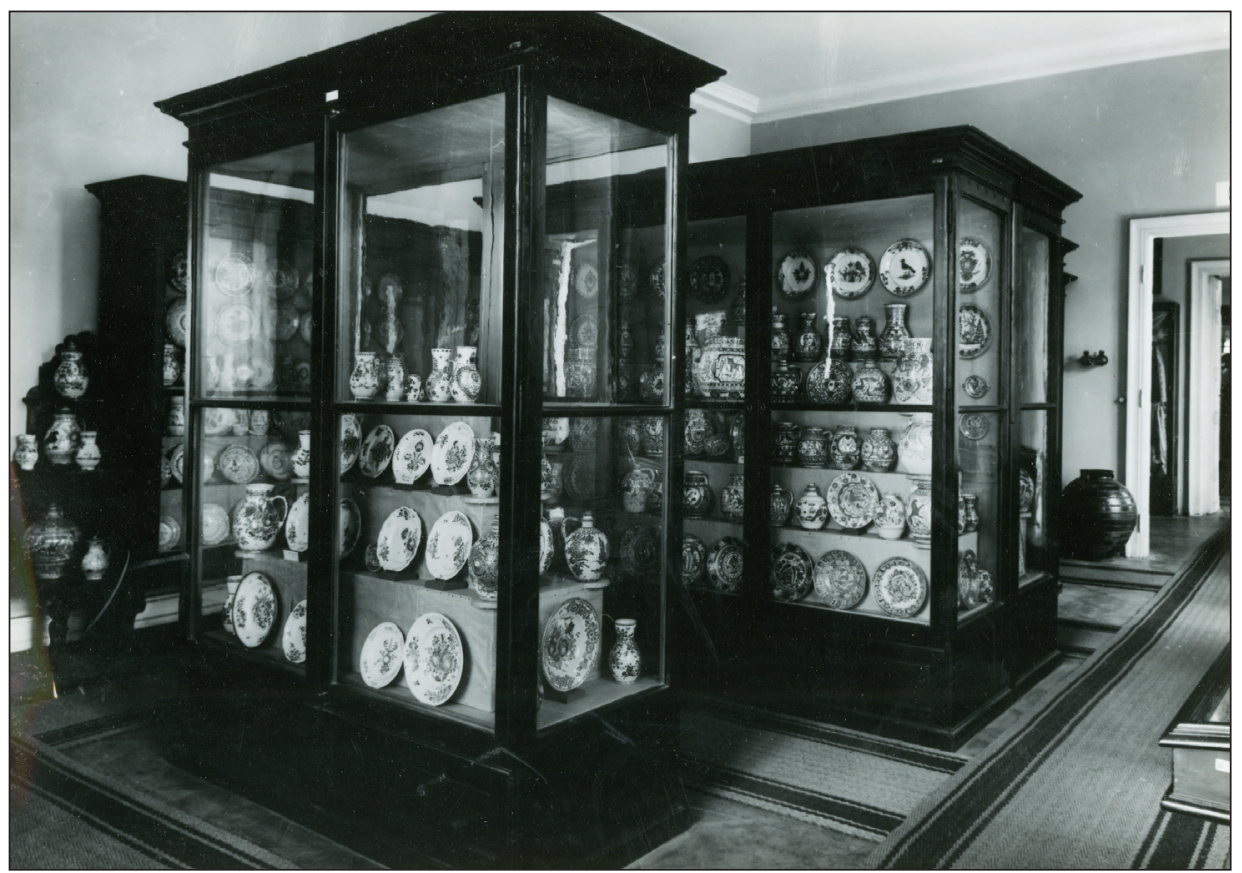

Obr. 2 Pohled do expozice v Letohrádku Kinských v roce 1928. ANM, fond OA etnografie, bez čísla. 


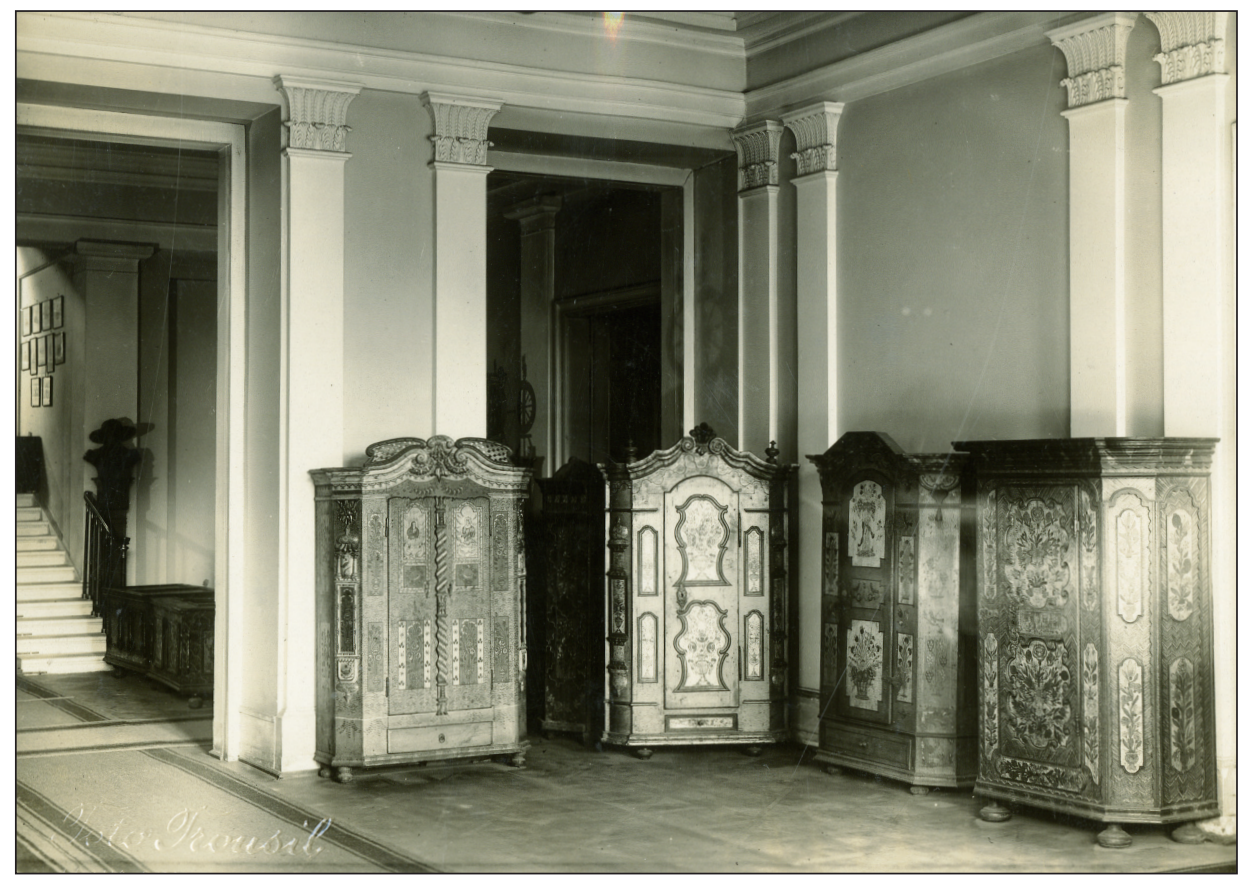

Obr. 3 Expozice venkovského malovaného nábytku ve vstupní hale Letohrádku Kinských. S.d. (foto Trousil). ANM, fond OA etnografie, č. 13324.

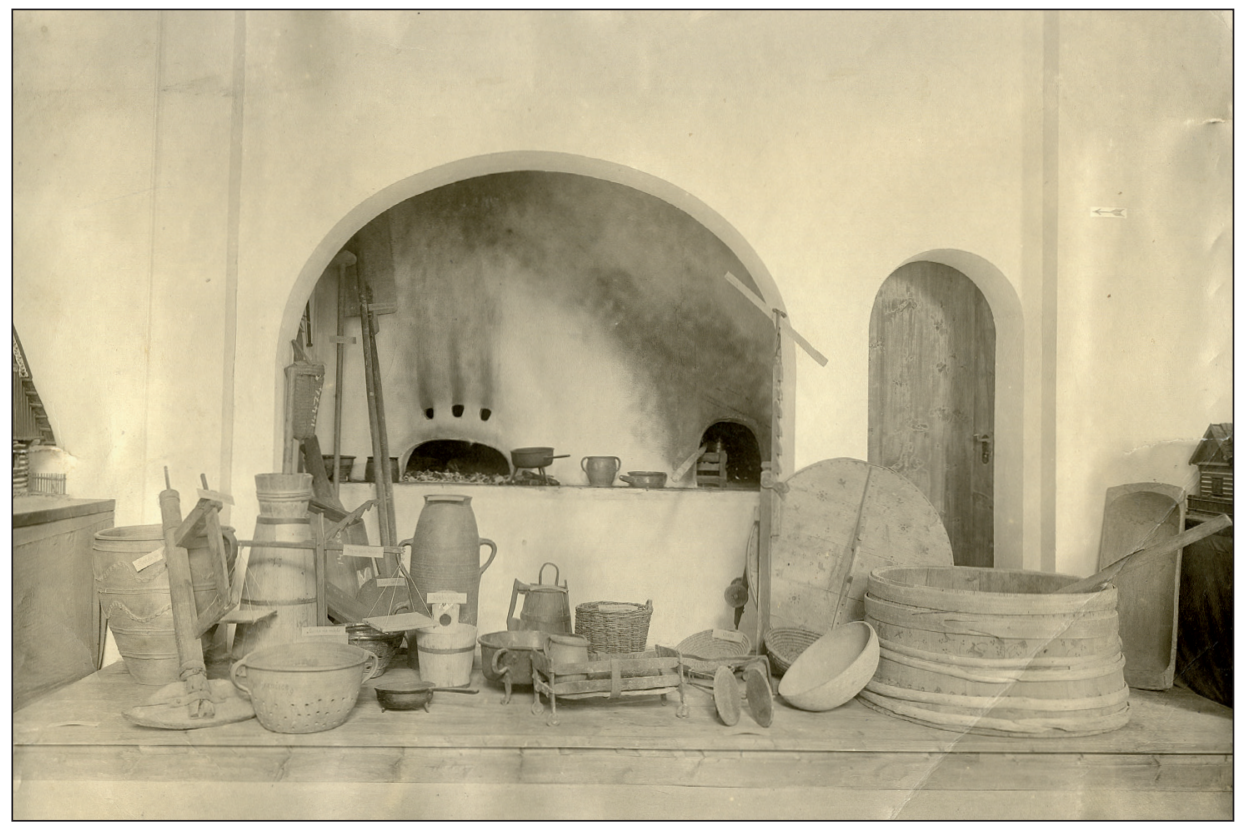

Obr. 4 Černá kuchyně v Zemědělském oddělení Národopisného musea českoslovanského (foto J. Štenc). ANM, fond Obrazový archiv etnografie (dále OA etnografie), č. 3865. 
Samotný Letohrádek byl však již v té době značně zaplněn předměty shromážděnými a prezentovanými Národopisnou společností českoslovanskou a spojením obou institucí došlo ještě k většímu zahuštění. Přesun sbírek měl i další negativní rys - z centra Prahy se nyní ocitly, byt se nám to tak dnes nemusí zdát, na samém okraji města. To se projevilo především na nízké návštěvnosti (jak konstatoval V. Fabian v roce 1923 „návštěva byla ve všedních dnech slabá"), ${ }^{24}$ a tedy i na malých tržbách ze vstupného a šatny, které jinak představovaly jeden $\mathrm{z}$ mála vlastních pravidelných příjmů, které Muzeum mělo (obecně je možno říci, že vstup a „garderoba“ každoročně přinášely čtvrtý třetí nejvyšší př́ijem - po zemské a státní dotaci - tj. asi $19 \%$ z celkových příjmů). Navíc si pracovníci i návštěvníci stěžovali, že národopisná expozice je daleko.

Národopisná sbírka se tedy jako první ze všech stěhovala do „dependance“, nicméně příliš mnoho výhod jí to nepřineslo. Prostorové obtíže se jí tím vyřešit nepodařilo a ani výraznější míra autonomie (at' již finanční, či správní) nepřicházela za současného způsobu řízení celé instituce v úvahu. K volnému použití mělo každé oddělení přidělenu pouze minimální částku a každý vyšší náklad bylo nutno konzultovat nejprve s vedením Muzea, které však také nerozhodovalo samostatně, ale bylo závislé na rozhodnutí zemského úřadu. Větší vzdálenost se tak stávala spíše nevýhodou.

Budova samotná a její správa představovala pro Muzeum také nemalé břemeno. Při převzetí nebyla rozhodně v dobrém stavu a rozsáhlejším investicím zprvu bránily pouze krátkodobé nájemní smlouvy s městem Prahou, jíž Letohrádek náležel. Až po roce 1924 byla smlouva prodloužena na 25 let a zemský správní výbor se tedy odhodlal k rozsáhlejším investicím, kterých bylo tou dobou již věru zapotřebí (jednalo se především o kroky směřující k zajištění suchého prostředí pro sbírky, nebot' vzhledem k umístění v parku byl v Letohrádku neustálý problém se zatékáním). ${ }^{25} \mathrm{I} v$ pozdějších letech však bylo zapotřebí častých úprav a dohady se stavební firmou, která byla těmito zakázkami pověřována, byly pak většinou během na dlouhou trat'. Vnitřní údržba však byla postupně vylepšována počínaje světlým vymalováním místností přes zajištění elektrického osvětlení skříní či pořízení vysavače prachu. ${ }^{26}$

Dosti problematické bylo v Letohrádku zabezpečení sbírek. Tato věc se začala intenzivněji řešit především v letech 1928 a 1929, poté co došlo v květnu roku 1928 k rozsáhlé krádeži v hlavní muzejní budově. Přednosta oddělení navrhoval ustanovení jednoho, či dokonce dvou nočních hlídačů, kteří měli být vyzbrojeni revolvery a kteří by dleli v Letohrádku po uzavření sbírek. Výsledkem však v tuto chvíli bylo pouze zavedení telefonu s nočním spojením 
do bytu vrátného. Linka se měla aktivovat při porušení dveří či oken. ${ }^{27}$ Jak ovšem správně poznamenali všichni odpůrci poměrně polovičatého opatření, tento signál měl smysl pouze ve chvíli, kdy byl správce doma. Ve stejné době se také začal klást důraz na protipožární opatření a celá budova byla vybavena různými typy hasicích přístrojů firmy Poleo. Vnitřním problémem byla např́ílad také ochrana vystavených exponátů před světlem, která se v tomto případě řešila natažením žlutého celofánu do oken..$^{28}$

Národopisné oddělení bylo v letních měsících otevřeno krom nedělí a svátků každý den, od 9. do 14. hodiny (v zimních bylo ve všední den zavřeno, protože v expozici nebylo možné vytopit při omezených zdrojích na více než 14 stupňủ Celsia a zájemců bylo beztak poskrovnu ${ }^{29}$ ), ovšem pokud byla na neděli objednána větší skupina návštěvníkủ či si přál prohlédnout sbírky některý z významných domácích a zejména zahraničních badatelů, bylo takovému přání většinou vyhověno, avšak o nedělích se neposkytoval v expozici výklad. $O$ individuálních návštěvnících mnoho informací nemáme, v př́ípadě skupin se jednalo bud' o návštěvy organizované například Čedokem, ${ }^{30}$ či objednané bez zprostředkování, či ještě častěji přicházely výpravy školní mládeže. Posledně jmenované pak většinou bývaly do výstavních sálů pouštěny zdarma.

Spíše úsměvnou zápletku z každodenního fungování národopisného oddělení představuje drobný spor o jeho název a vnější prezentaci. V roce 1932 byla totiž D. Stránská napomenuta muzejním prezidiem, že neoprávněně používá razítko a hlavičkový papír s textem Národopisné muzeum, že oddělení není samostatnou jednotkou, nýbrž muzejním oddělením. Sice byla přislíbena okamžitá náprava situace, ale jak ukazují další písemnosti v registratuře, zásoby takto předtištěného papíru byly značné a používal se v rámci úspor ještě poměrně dlouhou dobu. ${ }^{31}$

Jedním z hlavních rysů každodennosti v Letohrádku se ovšem velmi záhy stal zápas s nedostatkem místa. Bylo třeba zabezpečit pracovny pro pracovníky oddělení a případné badatele, ale měly zde také být nejen vystavovány, ale i ukládány veškeré sbírky. Situace byla opravdu komplikovaná, návštěvník by patrně byl překvapen, pokud by otevřel vystavené truhly a skříně, nebot' byly většinou po okraj naplněny menšími předměty náležejícími ke studijní části sbírky. Sbírky se také ukládaly v podstřeší v blízkosti komínů, což samozřejmě odporovalo bezpečnostním předpisům. Možná trochu paradoxně, 
vzhledem k různým střetům se Zemědělským muzeem, se později dožadovala Drahomíra Stránská ve 30. letech uložení rozrůstajících národopisných sbírek v již vícekrát zmíněné Švýcárně (která disponovala třemi sály a stejným počtem kanceláří a skladišt'), ovšem její úsilí bylo marné. ${ }^{32}$ Nakonec tedy muselo dojít na velmi nepopulární, ale naprosto nutné umenšování výstavních prostor, z nichž některé byly přeměněny na depozitáře (v tehdejší terminologii označované jako skladiště). ${ }^{33}$

Druhým problémem pak byl boj s nedostatkem financí, který byl ovšem také vlastní celému Národnímu muzeu. Srovnáme-li náklady na chod národopisu a pořizování sbírek, musíme spravedlivě konstatovat, že národopisné oddělení na tom relativně nebylo zle. Pokud odmyslíme náklady na knihovnu NM (která však ve svém rozpočtu měla započítány prostředky na nákup knih pro všechna odborná oddělení), jeho rozpočet býval mezi třemi nejvyššími.

\section{Národopisná sbírka}

Budování národopisné sbírky bylo pochopitelně jednou z hlavních náplní existence národopisného oddělení, na tomto místě ji však pochopitelně nelze zmapovat $v$ celé komplexnosti, pozornost tedy bude spíše zaměřena na některé zajímavé tendence, které můžeme ve sledovaném období vypozorovat (povšechný přehled hlavních rozsáhlejších akvizic té doby srv. in Mevaldová - Tauberová: 30-39).

Již bylo výše naznačeno, že základ národopisných sbírek byl položen na materiálech obou velkých výstav konce 19. století, které však nebyly v Národním muzeu uloženy kompletně, nýbrž byly rozděleny do více institucí. V některých př́padech putovaly zpět do oblastí, z nichž pocházely, a položily tam základ místních národopisných muzeí. Navrácení na výstavu zapůjčených předmětů také očekávali i někteří jejich původní vlastníci, ovšem přiznejme, že často toto očekávání bylo naplněno až po urgencích a v některých př́ípadech se již věci nevrátily původním majitelům vůbec. Také byla podrobně učiněna zmínka o sjednocení sbírek Národopisného muzea českoslovanského s menším souborem národopisného materiálu chovaného v Národním muzeu. ${ }^{34}$ Tyto dva celky byly spojeny společným inventářem a v podstatě splynuly (do té doby byly inventáře v Letohrádku vedeny pro každou místnost zvlášt', což zapříčiňovalo časté zmatky v případě přemístění předmětů). ${ }^{35}$ Vytvoření

32 ANM, RNM, k. 127, č. j. 318/35. Návrh na převzetí staré budovy Zemědělského musea v Kinského zahradě na Smíchově, 18. 6. 1935.

33 ANM, RNM, k. 139. Nedatovaný rozklad D. Stránské kuratoriu Národního muzea.

34 Pro úplnost ještě dodejme, že z exponátů národopisné výstavy byly odděleny předměty dokumentující zemědělství, které byly svěřeny zemědělskému oddělení Národopisného muzea a posléze se na jeho základech osamostatnilo Československé zemědělské muzeum. 
jednotného inventáře však byl dlouhodobý úkol, jednak kvůli poddimenzovanému stavu zaměstnanců a jednak také, jak si stěžoval vedoucí oddělení Václav Fabian, protože „vyhledávání předmětů v různých zákoutích a zásuvkách a jich ukládání zase působí značné průtahy...“" ${ }^{36}$ Naopak byly od sbírky odlučovány předměty, které patřily dle uvážení správce sbírky spíše k jiným oddělením (asi nejčastěji k historické archeologii), či dokonce jiným institucím (to se týkalo především nezdobeného zemědělského náčiní, které bylo postoupeno Československému zemědělskému muzeu). ${ }^{37}$ Trojrozměrná sbírka byla zprvu nazývána sbírkou předmětů a výšivek a sem byly včleňovány všechny další akvizice, at již přišly do Národního muzea darem, či koupí.

Dary byly pochopitelně maximálně vítány, nebot prostředky na nákupy byly velmi omezené. Jednotlivci však takto postupovali, především pokud chtěli do Muzea uložit zajímavou jednotlivinu.

Pokud Muzeu došla nabídka na odkup větších celků, bylo nutno většinou spoléhat na podporu státu či země ve formě mimořádných dotací. Takto získané sbírky však byly potom pochopitelně v majetku státu či země a v Národním muzeu byly pouze trvale deponovány. Jako př́klad takových velkých akvizic můžeme uvést hned dvě nabídky z roku 1922: sbírku Josefa Beránka (oceněna majitelem původně na 240000 Kč) a Anny Jehličkové (na 350000 Kč). Jako první v takovém případě byl vyslán odborný pracovník oddělení, který se snažil požadovanou cenu poněkud snížit, a o ceně se pak vyjednávalo. Vyřešení takto nákladných koupí se mnohdy táhlo i více než rok, v př́ipadě Beránkovy sbírky to bylo ještě déle, nebot́ záležitost byla uzavřena až v prosinci roku $1924^{38}$ a záležitost Anny Jehličkové nebyla uzavřena ještě ani v roce $1926 .{ }^{39}$ Postupem času se situace nelepšila, jak ukázala o několik let později kauza Lukáškovy sbírky výšivek, jejíž koupě se řešila skoro deset let a znamenala pro přednostu oddělení nejednu trapnou situaci, když musel (či později musela) vysvětlovat, proč se opět zpozdila již na pevno slíbená platba. Bez obalu řečeno, takto velké prrírůstky představovaly pro Muzeum zcela neřešitelný problém. Napříště se tedy z velkých sbírek vybíraly pouze nejvýznamnější a nejzajímavější předměty a pořizovaly se na splátky z mimořádných dotací na udržování sbírek.

S koupěmi drobnějších předmětů či menších souborů tyto potíže nebyly. Znamenaly však pro oddělení značnou administrativní zátěž. S tehdejšími technickými možnostmi se nabízené předměty musely do národopisného oddělení posílat poštou či doručit osobně, byly prohlédnuty a ohodnoceny a pak bud' zakoupeny, či posílány zpět. Kupodivu tento poměrně komplikovaný systém celkem fungoval, urgencí nevrácených či zatoulaných předmětů 
bylo jen pomálu. Praktičtější bylo nabízet předměty prostřednictvím fotografií, ale i v tom případě většina nabízejících požadovala vrácení fotky zpět do svého držení. Nebyla-li možná ani jedna z uvedených cest, vydávali se odborní pracovníci na sběrné výpravy, během nichž si nabízené předměty prohlíželi př́ímo na místě.

Zcela specifickou částí národopisné sbírky byl obrazový archiv. O jeho budování se zasloužil v počátcích především první přednosta oddělení Václav Fabian. Zatímco pro jiné sbírky bylo relativně snadné (tedy samozřejmě za předpokladu dostatečného financování) přiřazovat nové a nové předměty do sbírek, národopisné oddělení bylo často odkázáno na pouhé zdokumentování existujících staveb, oděvů či zvykosloví (či nabízených předmětů). Bylo využíváno různých metod. V meziválečné době již bylo rozšířeno fotografování, největší část obrazového archivu tedy tvořily přirozeně fotografie (pozitivy, v dobové terminologii označované jako kopie, i negativy), ale nemalou část představovaly i kresby různými technikami, či dokonce malby. Obrazový archiv byl velmi hojně využíván, v registratuře oddělení najdeme celou řadu žádostí o zapůjčení negativu či zhotovení pozitivní kopie pro účely publikování v novinách či knihách nebo pro nejrůznější výstavy.

Krom menších celků a jednotlivin, které do něj postupně přibývaly, zmiňme na tomto místě jako příklad jednu konkrétní rozsáhlejší akvizici, a sice soubor 1700 skleněných negativů s národopisnou tematikou fotografa Emanuela Málka, který daroval oddělení podnikatel J. J. Frič v roce 1934. Podmínkou bylo, že právo první reprodukce vybraných fotografií bude mít známý architekt Dušan Jurkovič a že budou vyhotoveny muzejním fotografem kopie sbírky. Jednalo se o dar skutečně mimořádný rozsahem i významem, s oběma stanovenými podmínkami však nastal časem problém. Dušan Jurkovič se snažil muzejní kuratorium přesvědčit, že jeho práva vůči sbírce nejsou prioritní, ale naopak výhradní (čímž by ovšem dar neměl pro Muzeum smysl, pokud by jej nemohl využívat) a v roce 1935 se kolem této otázky rozvinula nepř́ijemná a konce nemající korespondence.

Naplnění druhé podmínky bylo ještě komplikovanější a poukázalo na fakt, že ještě ve 30 . letech 20. století disponovalo Národní muzeum pouze jedním fotografem, který vyřizoval agendu všech odborných oddělení. Drahomíra Stránská s tímto fotografem, Františkem Tvrzem, vedla mezi lety 1934-1937 takřka neustálé spory: v registratuře je zachována celá řada vzájemných stížností. Je ovšem pravdou, že z národopisného oddělení pocházelo více než 32 \% všech fotozakázek ${ }^{40}$ a ovšem také je nepopiratelným faktem, že ještě v roce 1937 nebyly kopie pro rodinu Fričovu hotovy. Jak psala dr. Stránská: „Již delší dobu musím se př́imo vyhýbati společnostem a příležitostem, kde bych se $s$ dr. Fričem a jeho rodinou setkala, protože nemohu odůvodniti, proč jim kopie 
stále neposílám...“41 Pokus vyřešit komplikovanou situaci s pořizováním fotografií zakoupením vlastního fotoaparátu pro národopisné oddělení, který by bylo možno brát s sebou i na badatelské cesty, nevyšel. ${ }^{42}$

Ještě ve 20. letech minulého století byl také položen základ dalšímu specifickému souboru, sbírce, která měla shromažd’ovat „filmy, které předvádějí lidové obyčeje a slavnosti v krojích."43 Dodnes v etnografickém archivu chované filmové kotouče dokládají, že i tento směr dokumentování lidové kultury našel svůj ohlas, ovšem vývoj této sbírky nebyl zdaleka tak dynamický jako v prrípadě obrazového archivu. Od roku 1927 je také samostatně evidována sbírka papírových archiválií. Jak obrazový, tak filmový a papírový materiál je od roku $2016 \mathrm{v}$ péči Archivu Národního muzea.

Sbírky v první řadě sloužily veřejnosti v expozicích a výstavách, jak o tom bude podrobněji pojednáno, nicméně svůj význam měly samozřejmě i jako vědecké soubory navštěvované odborníky. Bylo zvykem, že přednostové oddělení informovali o počtech badatelů ve výročních zprávách svých oddělení, bohužel Václav Fabian i Drahomíra Stránská tento údaj systematicky opomíjeli, můžeme však na základě dochované korespondence konstatovat, že do sbírky čile docházeli jak domácí, tak zahraniční hosté z nejrůznějších institucí, především evropských.

\section{Výstavní činnost}

Základem výstavní činnosti Muzea (a národopisné oddělení nebylo v této věci žádnou výjimkou), tvořily řečeno dnešní terminologií stálé expozice.

První národopisná expozice byla vybudována ještě v budově na Václavském náměstí pod patronátem Jana Kouly. Jednalo se o tzv. Selskou síň, která byla v podstatě do jisté míry přetavená Česká chalupa realizovaná v rámci Všeobecné zemské jubilejní výstavy v Praze roku 1891. Když byla tato expozice v roce 1894 otevřena, jednalo se o vpravdě převratnou událost, nebot', jak poznamenala Drahomíra Stránská, „tím vstoupil český lid pod střechu Musea království českého a lidové umění bylo přijato mezi církevní, šlechtické a měštanské památky jako rovnocenné dědictví národa.“ (Stránská 1949: 126). Později byl tento sál doplněn ještě dalšími dvěma prostorami, v roce 1894 jedním s materiály Moravy, Slezska a Slovenska a na přelomu století byla také realizována expozice cizího národopisu).

Na budování nové expozice se začalo pracovat v Letohrádku Kinských v roce 1923 po ukončení stěhování původní národopisné sbírky z Václavského náměstí. Jako první se úprav dočkal vestibul a čtyři výstavní síně, s reinstalací 
dalších se pokračovalo v následujících letech ${ }^{44}$ a právě tyto úpravy se staly podnětem ke chvále, která zazněla z úst jednatele Společnosti NM, když označil, jak je uvedeno v nadpisu tohoto textu, národopisné oddělení za chloubu Muzea. Národopisná expozice pak byla inovována v roce 1933 po skončení krátkodobé výstavy o Slovensku. Když si pak správní výbor vyžádal odborný posudek na novou expozici od prof. Jiř́ího Horáka, bylo konstatováno, že „instalace doznala podstatného zlepšení proti stavu dřívěšímu a že zvláště byla instalována část zvykoslovná zcela nově.“45

Expozice v Letohrádku byly později znovu upravovány vždy v souvislosti s likvidací krátkodobých výstav, postupně se však prostor pro ně určený zmenšoval, protože některé sály musely být přeměněny na skladiště. Jak píše Drahomíra Stránská ve svém rozkladu zemským úřadům, „,v zahradě Kinských vlhnou a rezavější špendlíky i v létě... národopisné sbírky jsou uloženy ze všech oddělení Národního musea nejhůře a nejskrovněji, ba že jsou ze všech museí pražských nejstísněnější...“46

Období první republiky bylo zvykem jednotlivých sbírkových oddělení udržovat a inovovat své expozice $\mathrm{v}$ přidělených sálech a krom nich pořádat také dočasné výstavy, avšak nebylo jich rozhodně takové množství, jaké je v muzejní praxi dnes. Speciální agendu však představovalo i zapůjčování muzejních předmětů do zahraničí na výstavy, na jejichž pořádání se podílelo ministerstvo zahraničí a které měly v cizině prezentovat Československou republiku a její kulturu.

Podívejme se nejprve na krátkodobé výstavy. Na rozdíl od hlavní muzejní budovy, kde pro příležitostné výstavy jednotlivých oddělení nebylo příliš mnoho prostoru, byly v Letohrádku již od reinstalace v roce 1924 jmenovitě vyčleněny dvě místnosti pro pořádání „občasných výstavek“. Počátky těchto aktivit však byly spíše nesmělé. Prvotním impulsem pro ně nebyla touha představit například novou akvizici či zajímavý soubor předmětů k určitému regionu, ale jednalo se o doprovodné akce různých vědeckých setkání. Jako první se konala taková výstava při příležitosti sjezdu československých a slovanských národopisných pracovníků v roce 1923 a koncem téhož roku při mezinárodním sjezdu antropologů a etnografů. Na tyto podniky pak navázaly další dvě výstavy, které již předurčovaly budoucí směr tematických výstav: jednak lužicko-srbská výstava v roce 1924 a v roce následujícím výstavka obrazů s národopisnou tematikou malíre Waldhausera. ${ }^{47}$

44 ANM, RNM, k. 99, spis Výroční zpráva za rok 1923. Strojopis výroční zprávy národopisného oddělení, 7. 2. 1924.

45 ANM, RNM-SNM, k. 1. Zápis o schůzi správního výboru Národního musea konané dne 15. března 1934.

46 ANM, RNM, k. 139. Rozklad D. Stránské, Z. Wirtha a K. Chotka kuratoriu NM, nedatováno.

47 Exponáty z této výstavy byly posléze zakoupeny ministerstvem školství a národní osvěty a uloženy jako státní depozit právě v národopisném oddělení. 


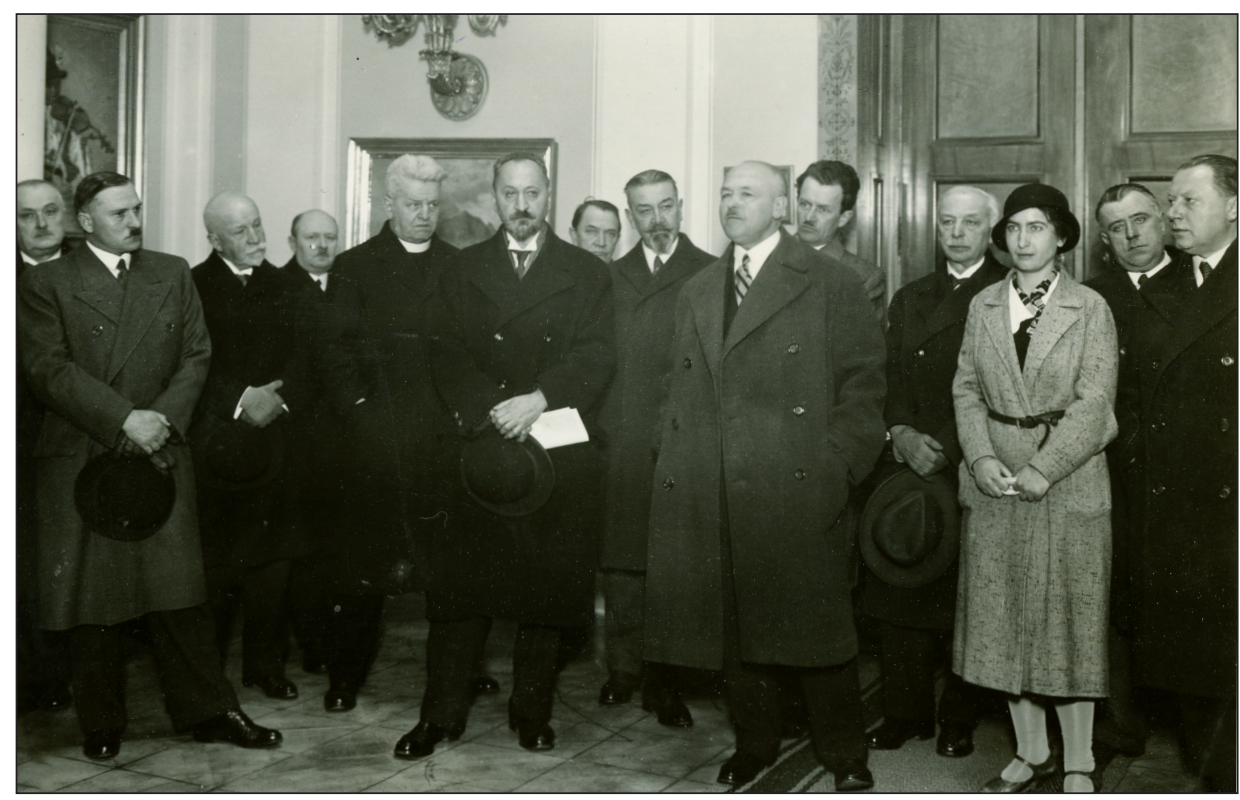

Obr. 5 Zahájení výstav v národopisném oddělení Národního musea Smíchov. 1933 (foto Centropress). ANM, fond OA etnografie, č. 13879.

Zatímco Fabianova éra byla co do pořádání těchto krátkodobých výstav spíše dobou hledání směrů a formátů, plně se tento fenomén rozvinul v období, v němž stála v čele oddělení Drahomíra Stránská. V té době bylo uspořádáno takových výstav několik. V prostém výčtu: v roce 1933 se jednalo o výstavu „Slovenské Tatry - kraj a lid“. Následující rok přinesl dokonce dvě výstavy, a sice „Lidová víra a pověra“ a také akci zaměřenou na „Lidové umění Dalmácie“. I rok 1935 se nesl ve znamení jižních Slovanů a pod názvem „Durmitor“ byly prezentovány obrazy i artefakty ilustrující život v tomto pohoří. V roce 1937 byla připravena výstava o Islandu a konečně v roce 1938 vrchol celé řady těchto tematických akcí, výstava „Bulharsko - země a lid““. ${ }^{48}$

Krátkodobé výstavy pořádala v různé míře všechna oddělení Národního muzea, na těch národopisných však můžeme velice dobře ilustrovat některé příznačné jevy tehdejší muzejní praxe. Hned první slovenská výstava přinesla významný impuls, který byl v národopisných výstavách v pozdějších letech významně rozvíjen (velmi silně u všech výstav zaměřených na jihoslovanskou problematiku a vrcholu dostoupily potom v poslední bulharské výstavě). Zatímco muzejní knihovna byla v pořádání „výstavek“ také velmi

48 K posledně jmenované výstavě se dochovala mimořádně celistvá dokumentace svědčící o značné organizační náročnosti celého podniku, včetně účetních dokladů, jejichž revizi nařídil zemský úřad, nebot́ závěrečné vyúčtování předložené Drahomírou Stránskou vykazovalo celou řadu nedostatků a nebylo úplné (celá záležitost byla uzavřena až v roce 1940). ANM, RNM, k. 140, spis Bulharská výstava. 


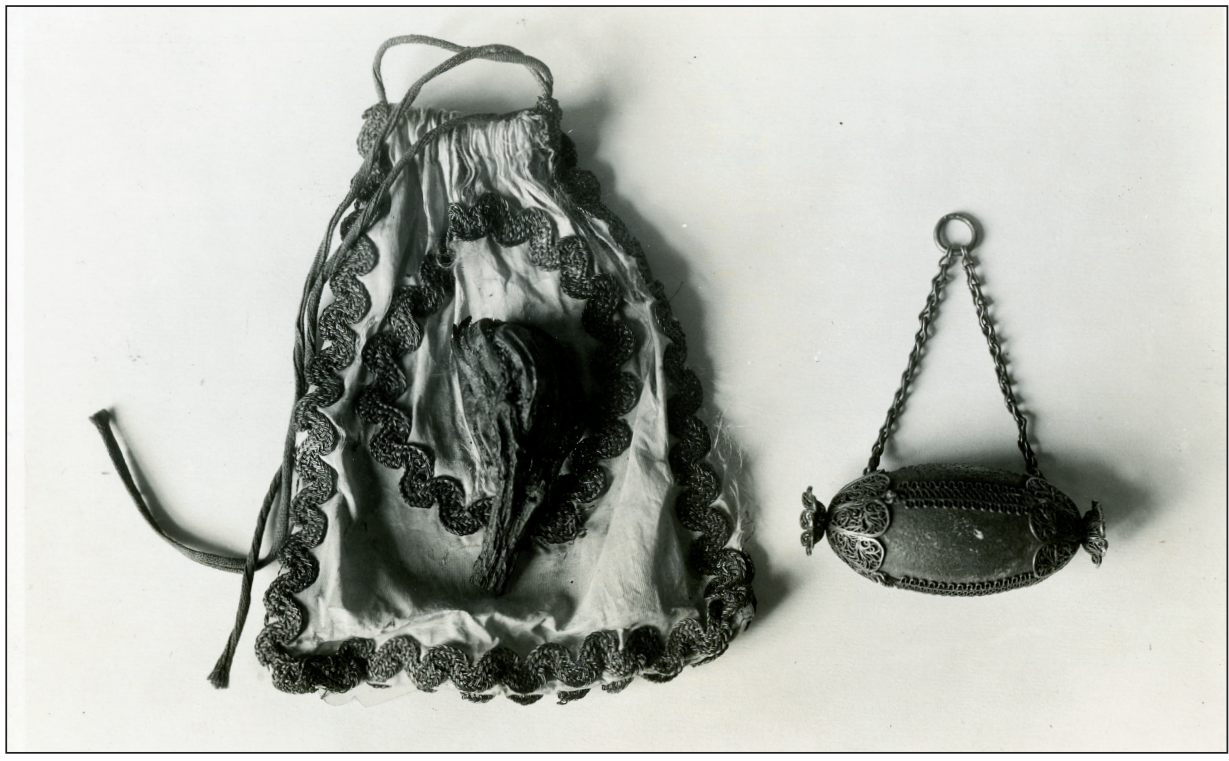

Obr. 6 Sáček s mandragorou a neopracovaný šedý kámen v upevnění ze zlata proti moru. Vystaveno 1934 na výstavě Lidová víra a pověra. (foto Centropress). ANM, fond OA etnografie, č. 14821.

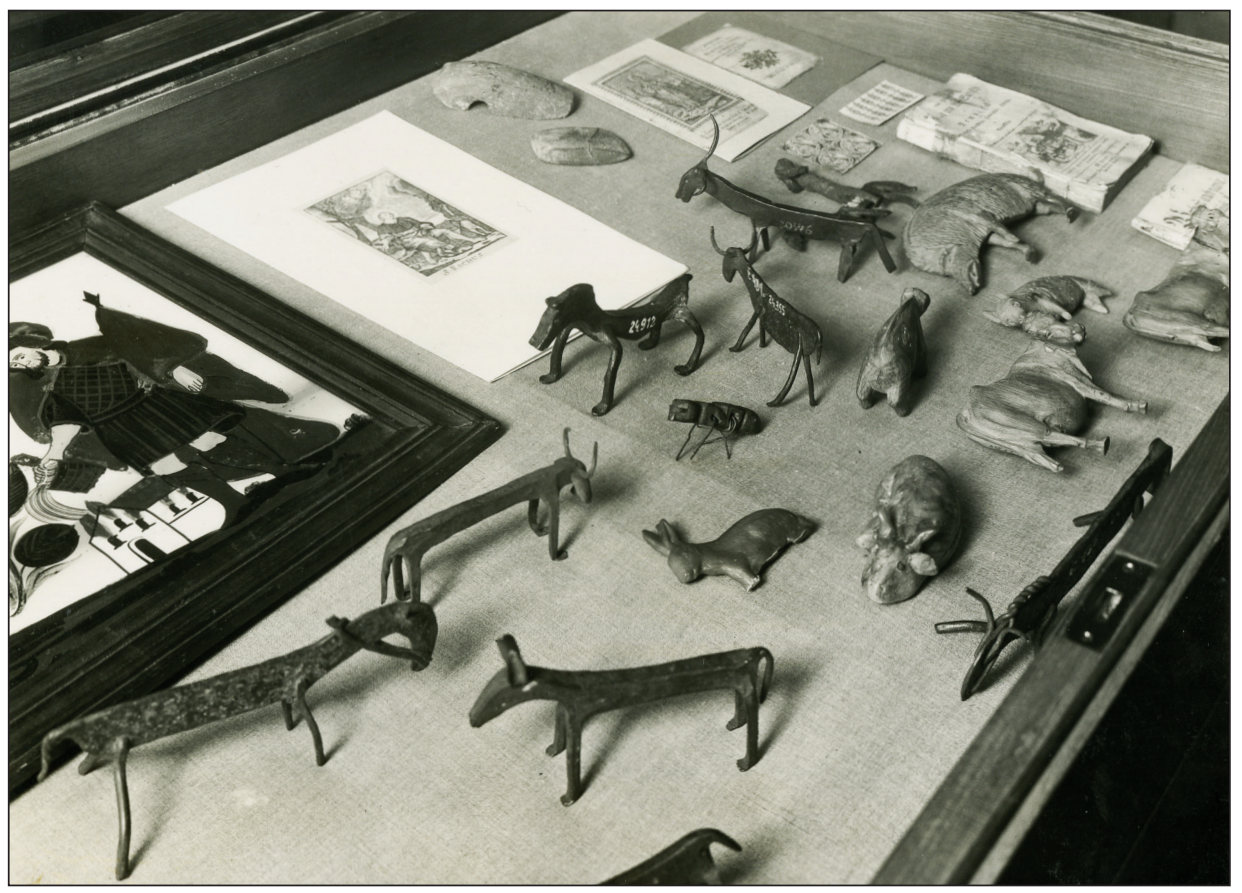

Obr. 7 Předměty pro ochranu dobytka, vlevo obětní zvířátka votivní z vosku (kravička a králíček). Vystaveno 1934 na výstavě Lidová víra a pověra. (foto Centropress). ANM, fond OA etnografie, č. 14825. 


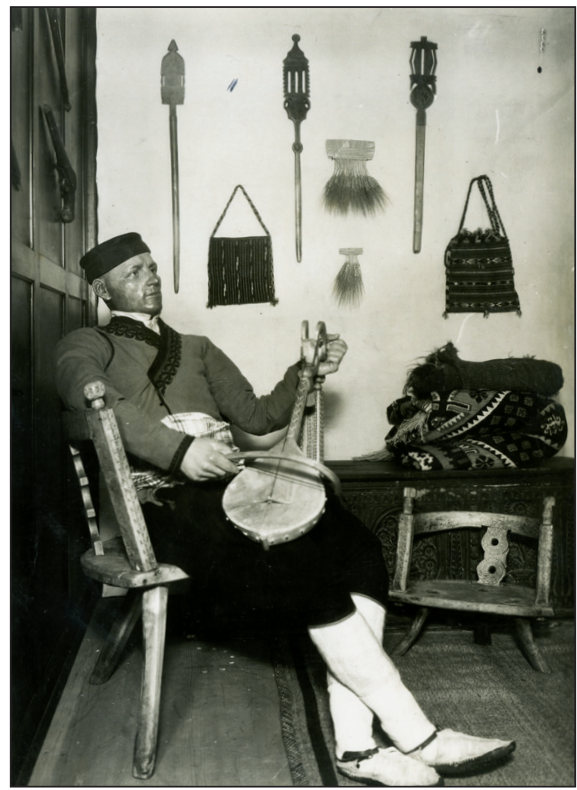

Obr. 8 Durmitor. Figura Černohorce vytvořená pro výstavu jihoslovanského lidového umění. 1935 (foto Centropress). ANM, fond OA etnografie, č. 14852.

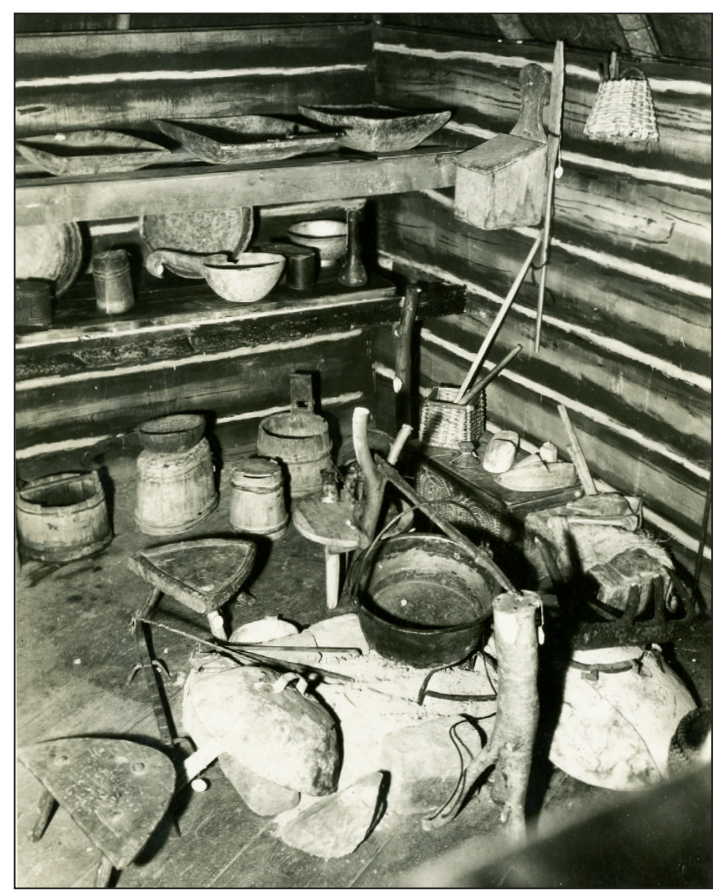

Obr. 9 Durmitor. Část interiéru salaše zkonstruované při výstavě jihoslovanského lidového umění. 1935 (foto Centropress). ANM, fond OA etnografie, č. 14851. 
aktivní a v některých letech jich byla schopna zorganizovat i osm, prezentovala na nich většinou předměty již se ve sbírkách nacházející - bud' podle tematického výběru (výročí významných událostí, životních jubileí spisovatelů či umělců atd.), nebo byly prezentovány i nedávné akvizice (výstavy nejnovějších přírůstků). Ne tak v národopisném oddělení. Stanovení tématu výstavy se stávalo mocným impulsem pro dlouhodobější výzkumné cesty a získávání nových akvizic, které doplňovaly komplexní obraz zvolené oblasti (geografické nebo tematické) v muzejních sbírkách. Tento celek byl pak prezentován. Pochopitelně by tento postup nebyl možný bez velmi výrazné podpory muzejního vedení (např. povolováním několikaměsíčních dovolených na cesty) a také bez štědrých dotací z různých stran (jak na cestu samotnou, tak na akvizice). Jen dodejme, že s takto „otevřenou rukou“ muzejního vedení se zdaleka nepotkávali přednostové všech muzejních oddělení.

Svou nezastupitelnou roli hrály ve výstavách národopisného oddělení také důvody ryze propagační. Na slovenské výstavě to byla třeba výrazná prezentace slovenské balneologie, která byla vytvořena př́mo ve spolupráci s ministerstvem zdravotnictví. Na téže výstavě se také podílel menší částkou i Klub československých turistů se stejným cílem, upozornit na Tatry jako zajímavou destinaci.

Zas trochu jiný postup ukazují přípravy na výstavu věnovanou lidové zbožnosti. Drahomíra Stránská tehdy podnikla rozsáhlou dotazníkovou akci, v níž oslovila nejen sběratele památek lidové kultury, s nimiž bylo oddělení tradičně ve styku, ale také nejširší veřejnost (prostřednictvím denního tisku) a po možných zajímavých talismanech se poohlížela také např́íklad mezi řidiči či piloty.

Krátkodobé výstavy národopisného oddělení byly mimořádné ještě v jedné věci související s jejich rozsahem a s tím související organizační náročností. Výstavy konané $\mathrm{v}$ hlavní budově bývaly rozsahem menší a nevyžadovaly tolik úprav výstavních sálů (ty navíc byly tak naplněné, že moc velká možnost k zásadnějším přesunům ani nebyla), etnografické výstavy v Letohrádku, alespoň pokud čteme jejich průvodce, znamenaly vyklizení větší části Letohrádku a jeho opětnou instalaci po skončení akce. Slovenská výstava zabrala 16 místností, bulharská pak stejně tolik. Po velkých výstavách tak mohla zároveň být upravena a modernizována i stálá expozice. Náročná organizace si také vyžadovala velký př́ípravný aparát (přípravný komitét, čestný výbor), což vzbuzovalo například ve správním výboru NM obavy, že role Národního muzea v celé akci nakonec zcela zanikne. ${ }^{49}$

Každá z výstav přinesla nejrůznější zajímavé momenty a vzruchy do života národopisného oddělení i celého Národního muzea. A bylo zjevné, že Stránská se těchto vzruchů nikterak neobávala. Ba právě naopak, byla ochotna 
pro své výstavy podstoupit i leckdy velmi komplikované jednání o zahraničních výpůjčkách a výstavy byly v mnoha případech i „interdisciplinární“ v tom smyslu, že neprezentovaly zdaleka pouze národopisnou problematiku a př́íslušné sbírky, ale také př́rodní poměry dané oblasti. To pochopitelně bylo možné i díky spolupráci s ostatními odděleními NM či př́ípadně specializovanými ústavy.

Zcela specifickou kapitolu vystavování sbírek představují akce zaštitované ministerstvem zahraničí, které měly Československo propagovat v zahraničí a tento „reklamní“ aspekt byl mnohem významnější nežli jakékoli hledisko odborné. Hned od počátku samostatného státu bylo zjevné, že Muzeum tyto akce a svou participaci na nich prŕliš nevítá, byṫ samozřejmě s ideou Československa se instituce od samého počátku plně identifikovala. Šlo spíše o bezpečnost sbírek. Obecně se totiž Společnost Národního muzea stavěla velmi skepticky k jakémukoli půjčování muzejních sbírek mimo budovu. V praxi vydával první stanovisko k zápůjčce správce př́íslušné sbírky a pak byla posuzována výborem Společnosti NM a také zemskými úřady. I přes kladné stanovisko kurátora nemusela být vůbec věc nakonec zapůjčena a rozhodovací praxe v těchto záležitostech nebyla rozhodně vždy konzistentní. Na misku vah padala celá řada okolností od podmínek vystavení přes zabezpečení a konče třeba podmínkami přepravy. Zejména v hubených poválečných či krizových letech mohlo být i obstarání posledně jmenovaného poměrně značným problémem.

Zatímco v letech krátce po vzniku republiky docházelo spíše ke změkčování praxe a muzejní sbírky byly zapůjčovány se vzrůstající ochotou, po roce 1928 se naopak poměry začaly opět utužovat. A jedním z iniciačních momentů tohoto zpřísnění se staly právě časté požadavky na propagační výstavky národopisného charakteru. Již v roce 1928 (možná v bezprostřední návaznosti na rozsáhlou krádež v muzejních sbírkách v květnu téhož roku) bylo na jedné ze schůzí usneseno, že „správní výbor napříště z národopisného oddělení půjčovati předmětů nebude, poněvadž sbírky Národního Musea nemají účel, aby se pomocí jich pořádaly propagační výstavy v cizině a propůjčování jich mimo budovu musejní jest vždy spojeno s risikem poškození nebo ztráty, které se pojištěním nedá vyvážit." ${ }^{50}$ Následujícího roku se pak opatření rozšíriilo např́íklad i na rukopisy a staré tisky z knihovny.

Obavy z poškození či ze ztráty muzejních předmětů se čas od času naplnily. Asi nejvýrazněji se tak stalo při př́ležitosti výstavy československého lidového umění v USA. Tehdy se vůbec nevrátilo 12 předmětů z 59 a Muzeu nezbylo než se po nepř́ijemných jednáních spokojit pouze s malým pojistným plněním, které však nastalou škodu zdaleka nenahradilo. Tato výstava 
nakonec navíc ani nesplnila svůj účel, protože nikde nebylo uvedeno, že předměty jsou z Národního muzea. ${ }^{51}$

Protože byly však tyto podniky považovány za potřebné a strategické a ministerstvo zahraničí se nerado spokojovalo s negativní odpovědí, byl zvolen jiný postup. Místo aby Muzeum zapůjčovalo, či dokonce natrvalo postupovalo za hranice své vlastní sbírky, podnikalo v případě nutnosti nákupní akci, která měla shromáždit příslušný reprezentativní soubor přímo na míru dané akce. Náklady v takovém případě hradila pochopitelně československá vláda. S postupujícím časem se však stávalo čím dál složitějším úkolem sestavit dostatečně bohaté vývozní kolekce, často bylo poukazováno na obtížnost získávání oděvních součástí. Nicméně i přes určité obtíže se nakonec předměty ilustrující život českého lidu vystavovaly v Pařriži (1927 - pleny, výšivky, 25 obrazů, ${ }^{52} 1937$ - světová výstava, kolekce 101 předmětů $\left.{ }^{53}\right)$, Kímě (Mezinárodní kongres pro hospodyňské vyučování, 1927, menší soubor na 14 dní54), Tokiu (1928), Amsterodamu a Bruselu (1929) a USA (1935-1936). Menší kolekce pak byly sestavovány i na př́mou žádost některých muzeí, která si přála československé exponáty převzít jako dar, takto tomu bylo například v roce 1932 $\mathrm{v}$ př́ípadě požadavku Victoria and Albert Museum v Londýně. ${ }^{55}$

\section{Vědecká činnost oddělení}

Jen máloco ukazuje nemalé ambice muzejní etnografie jako dva velké projekty spojené se sledovaným oddělením v meziválečné době. Prvním z nich byl přesun dřevěného kostelíka z obce Medvedovce na Podkarpatské Rusi, druhým potom plán na vybudování muzea v př́rodě. Oba dva velké projekty byly již v recentní literatuře podrobněji zpracovány (naposledy Mevaldová 2015, kde i dosavadní literatura), připomeňme je tedy pouze v základních rysech.

V prvním případě se jednalo o získání řeckokatolického dřevěného kostela, jeho rozebrání a převoz do Kinského zahrady a opětovné sestavení. Jednání o celé záležitosti započalo již v letech $1924^{56}$ a 1925 , kdy byla určena konkrétní stavba, která měla být přenesena do Prahy. Uvažovalo se na jedné straně o kostele ve vsi Šelestově, ovšem ten v Medvedovcích byl vyhodnocen

51 ANM, RNM, k. 135, č. j. 1014/37. Putovní výstava čsl. lidového umění v Americe, s.d.

52 V tomto případě byla situace obzvláště napjatá, protože ministerstvo si vzpomnělo na nutnost sestavení kolekce pro Paříž dva dny před tím, než měl na místo určení odcestovat kurýr. ANM, RNM, 1927, č. j.709. Ministerstvo zahraničí ČSR ředitelství národopisného muzea, 2. 11. 1927. ANM, RNM, k. 135, Antonín Zemek předkládá ministerstvu zahraničních věcí vyúčtování zálohy a seznam zakoupených věcí, s.d. 


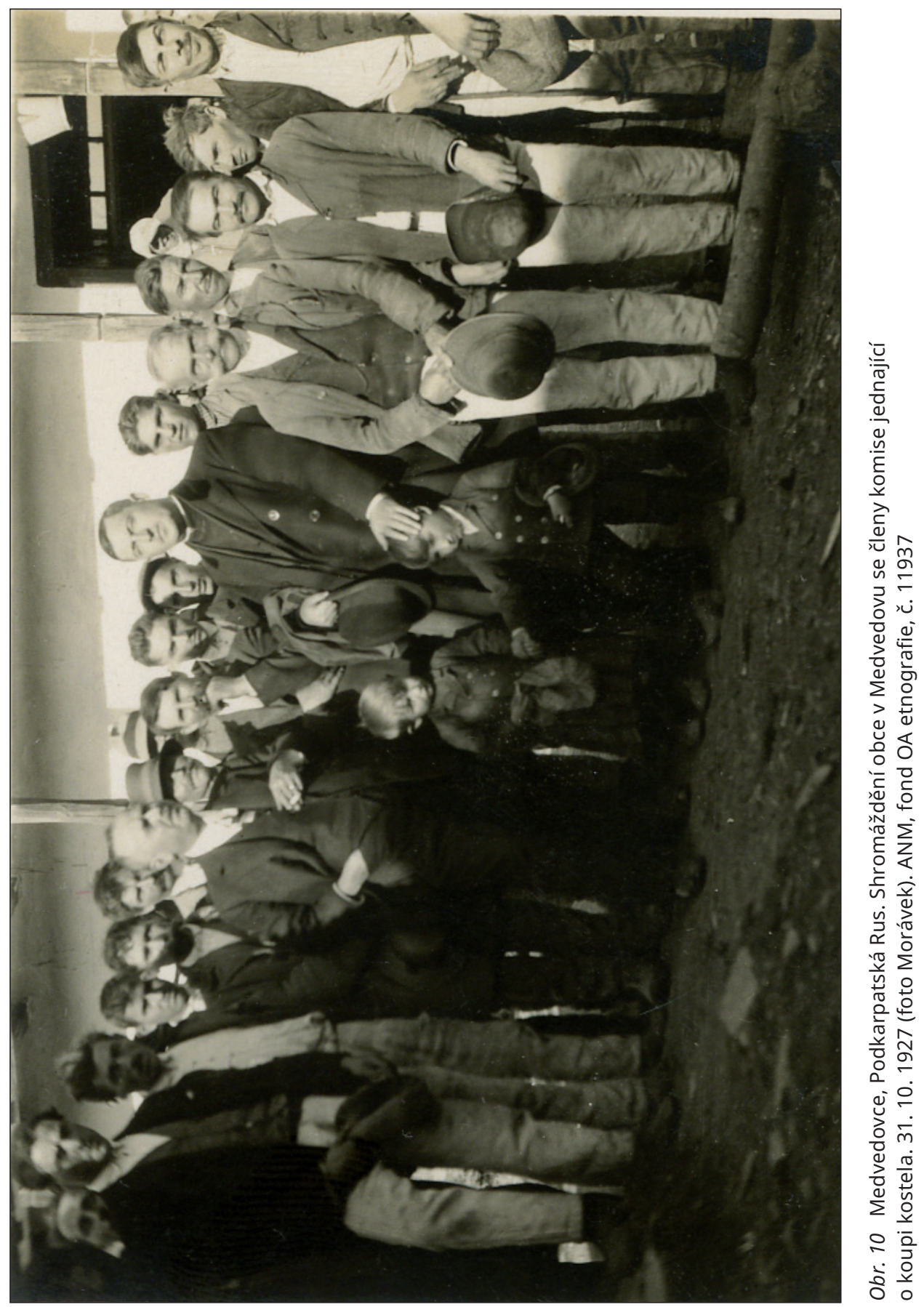


jako „pěknější“ a ve skutečnosti také předpokládané náklady měly být nižší. Započala složitá vyjednávání, která však vedla k úspěšnému konci až po letech. ${ }^{57}$

Proč se Národní muzeum, které samo zápasilo s nedostatkem pracovních kapacit i prostředků, pustilo do tak logisticky i finančně komplikované záležitosti? Důvody byly na jedné straně nepochybně odborné, na straně druhé však i politické. O odborných důvodech není sporu, přenášení zajímavých a ohrožených staveb a vytváření muzeí v přírodě bylo již v této době známou věcí (první takové muzeum, Skansen, byl založen již v roce 1891 ve Stockholmu). Politické pohnutky však sehrály možná ještě významnější roli. Zjednodušeně řečeno, Muzeum po vzniku Československa muselo, chtělo-li si udržet své postavení přední muzejní instituce, rozšírit svůj vědecký zájem z původně víceméně českého materiálu i na sbírky ze Slovenska a Podkarpatské Rusi. Na druhou stranu přenesení zajímavé podkarpatoruské stavby do hlavního města hrálo i pro nově vzniklý stát důležitou propagační úlohu, protože stavba přibližovala návštěvníkům Muzea dosud nepříliš známou, dosti vzdálenou a zcela novou součást republiky. Celý podnik nakonec financovalo ministerstvo školství a národní osvěty prostř̌ednictvím mimořádné dotace (přičemž původně odhadované náklady byly výrazně překročeny).

I přes angažmá centrálních úřadů a osobní zaujetí Václava Fabiana se nakonec podařilo akci dokončit až v roce 1929, přičemž zejména v roce 1928 se při příležitosti 10. výročí založení republiky zvýšil v této věci na Muzeum zcela nepokrytě i politický tlak.

Druhý projekt je již spjat s osobností Drahomíry Stránské. Poprvé již v roce 1935 předložila návrh zřízení pražského muzea v přírodě. Mělo se jednat o národní skanzen, takový, v němž by byly zastoupeny stavby z celého území republiky, a měl navazovat na proslulý stockholmský Skansen (srv. Stránská 1938). ${ }^{58}$ Ze všech uvažovaných lokalit Drahomíra Stránská nakonec vybrala pražskou Šárku a projekt byl pro toto umístění dosti podrobně rozpracován, dokonce ve dvou verzích, včetně návrhů konkrétních staveb a také včetně předpokládaného rozpočtu, ovšem z projektu nakonec sešlo.

Nemůžeme pominout ani tištěnou produkci národopisného oddělení. Osobní bibliografie jeho pracovníků ponecháváme na tomto místě stranou, byt samozřejmě v mnoha př́padech bezprostředně souvisely se spravovanými sbírkami (osobní bibliografie D. Stránské viz Hrdá 1999), ale podívejme se spíše na nejrůznější příležitostné tiskoviny. Jednalo se v první řadě o průvodce po expozici. Ty tvořily druhý díl seriálu, jehož první svazek představoval budovu a expozice budovy na Václavském náměstí (Průvodce 1932). Obsahem bylo krátké pojednání o samotném oddělení a hlavní důraz byl kladen na komentář

57 ANM, RNM-SNM, k. 1. Protokol o schůzi správního výboru Národního Musea, dne 28. listopadu 1925.

58 ANM, RNM, k. 127. Drahomíra Stránská zemskému úřadu, 12. 1. 1935; komplexně problematiku představuje spis Československé museum v přírodě v roce 1937 (tamtéž k. 137). 
k jednotlivým částem expozice a představení významných exponátů. $\mathrm{V}$ dnešní době tento žánr zůstává spíše ve stínu, nicméně v meziválečné době představoval pro návštěvníka jediný výraznější zdroj poučení o vystavovaných předmětech. Nebylo tehdy totiž zvykem doprovázet jednotlivé úseky expozice podrobnějšími texty, které by uvedly návštěvníka do příslušné problematiky. Jednotlivé předměty byly pochopitelně opatřeny popiskami, nicméně pojednání o širším kontextu chybělo.

Další tisky, které vycházely z národopisného oddělení, byly úzce spojeny $s$ výše zmíněnými krátkodobými výstavami. Jednalo se totiž o výstavní katalogy, jejichž podobě byla Drahomírou Stránskou věnována velká pozornost a byly doprovázeny v některých př́ípadech i odbornými studiemi. Asi nejpropracovanější v tomto směru byl katalog k bulharské výstavě v roce 1938.

\section{Závěr}

Národní muzeum vkročilo rokem 1918 do druhého století své existence a ve změněných podmínkách nově vzniklého samostatného československého státu se hrálo o mnoho. V první řadě o podobu Muzea samotného (jednání o postátnění či pozemštění), o jeho postavení v síti československých muzeí, o jeho úkolech a také o podobě jeho sbírek (mají-li mapovat vývoj v zemi či státu). Řešení těchto existenciálních otázek bylo samozřejmě především věcí jeho nejvyšších představitelů a jejich jednání se zemskými a státními institucemi, nicméně v některých ohledech se projevily bezprostředně i na fungování a osudech jednotlivých oddělení.

Národopisné oddělení je toho dobrým příkladem. V rámci centralizačních opatření směřujících ke sjednocování sbírek obdobného charakteru v jedné instituci k němu byla připojena většina sbírek Českoslovanského národopisného muzea, čímž se od základu změnila co do kvality i kvantity národopisná sbírka. Ve jménu stejných tendencí se ovšem pak, ještě za součinnosti s jistými politickými tlaky, táž sbírka málem celá octla mimo Národní muzeum. Celá akce, byt nepostrádala logiku a byla do jisté míry vedena dobrými úmysly, nakonec ztroskotala na řadě formálních nedostatků a národopisné oddělení zůstalo zachováno.

Oddělení národopisu se v meziválečné době potýkalo (stejně jako celé Muzeum) se třemi hlavními problémy: se všudypřítomným nedostatkem financí, nebot' ani v jediném roce se mu nedostalo tak vysoké podpory, o jakou v rozpočtu žádalo, a to i přesto, že požadavky byly vždy poměrně skromné. Druhým problémem byl pak nedostatek místa. Národopisné oddělení dostalo sice k dispozici celou vlastní budovu Letohrádku Kinských, ovšem ta sama již byla naplněna sbírkami Národopisné společnosti. Poslední velkou překážkou dynamičtějšího rozvoje celého oddělení pak byl malý počet personálu, a to jak odborného, tak technického. 
Oddělení se paralelně potýkalo také se svými vlastními vnitřními výzvami. Národopis se v té době nacházel na křižovatce mezi již antikvovaným pojetím uměnovědným, které reprezentoval první vedoucí samostatného oddělení národopisu Václav Fabian, a odborně národopisným, které naopak ztělesňovala jeho nástupkyně Drahomíra Stránská. Ta však stále zastávala i některá poměrně konzervativní až „starožitnická“ stanoviska. Nicméně i tak se střet těchto dvou koncepcí projevoval nejen při prezentaci národopisné sbírky před veřejností v expozicích a výstavách, ale, a to je mnohem podstatnější, se podepisoval také na sbírkotvorné koncepci. Opomíjením „méně krásných“ aspektů tradiční lidové kultury byla v té chvíli promarněna jedinečná šance na získání a dokumentaci předmětů či jevů, které později již nebyly k dispozici. Angažmá Drahomíry Stránské, at již v kterékoli instituci (Národní muzeum, Národopisná společnost, Slovanský ústav, Filozofická fakulta Univerzity Karlovy), bylo pro vývoj československého národopisu v této době mimořádně závažné. Jedním z jejích velkých projektů, který se však bohužel nepodařilo zrealizovat, bylo založení muzea lidové architektury v př́rodě v Praze.

Není sporu, že meziválečné dvacetiletí představuje ve vývoji muzejní etnografie velmi dynamické období, v němž byla nastartována celá řada aktivit, které po druhé světové válce pevně zakotvily v muzejní praxi a dále se modernizovaly a rozvíjely. Léta druhé světové války v tomto směru vývoj oddělení z nastoupené cesty již nezvrátila, pouze jej o několik let pozdržela. Řeč je hlavně o krátkodobých výstavních projektech, s nimiž po první světové válce Muzeum teprve začínalo a v národopisném oddělení získaly velice rychle pevné místo v programu prezentace sbírek a dosahovaly na jedné straně dobrých odborných kvalit, na straně druhé i pozitivního ohlasu u nejširší veřejnosti.

Na některých podnicích oddělení se ukazuje i další z aspektů, se kterými bylo třeba $v$ tehdejší muzejní praxi počítat, a sice moment propagační až ideologický. $V$ tomto případě je nutno hovořit především o propagaci nově vzniklého státu a jeho kultury v zahraničí, za druhé pak i v rámci domácích aktivit byly badatelsky „objevovány“ a veřejnosti prezentovány některé dosud méně známé regiony Československa, at již se jednalo o Slovensko, či Podkarpatskou Rus. 


\section{Příloha 1}

P.T. Zemskému správnímu výboru v Praze

Rada Společnosti Národopisného musea českoslovanského obrací se k zemskému správnímu výboru se zdvořilou žádostí, aby přijal do majetku země sbírky lidopisných památek (mimo památky zemědělské retrospektivy), které Národopisné museum českoslovanské nashromáždilo s tolikerým úsilím a nemalým nákladem hmotným za čtvrtstoletí svého trvání a aby tak vzácné a cenné památky ty, namnoze skutečné poklady lidového umění, ceny opravdu jedinečné zachoval pro budoucno intaktní a neporušeny na prospěch všeho národa, jako nevyčerpatelný pramen národní rázovitosti, posilující neobyčejnou měrou národní české sebevědomí stejně, jako nepostradatelný pramen všeho vědeckého bádání o českém životě lidovém.

Ke kroku tomu je musejní rada nucena krajně kritickou situací finanční, v níž se Národopisné museum československé přese vše její úsilí dnes ocitá. Prostředky musejní jsou tak omezeny, že nedovolují v posledních letech nejen další úspěšné rozmnožování musejních sbírek a tím zachování a zabezpečení materiálu dosud po různu dochovaného v majetku soukromém, ale nedávají již ani možnosti materiál nashromážděný opravovati s povinnou pečlivostí, konservovati jej a chrániti jej v plné bezpečnosti. Běžné př́jmy musea nestačí ani na udržování dostatečného personálu, který by musejní památky mohl řádně spravovati a ručiti za jejich neporušené zachování. Ač musejní rada jistě krajně na platech personálu šetř́í, ač personál je omezen co do počtu na míru nejskromnější, přece samy výdaje osobní u Národopisného musea českoslovanského převyšují pravidelné musejní příjmy. Při tom Národopisné museum českoslovanské je dnes bez dostatečného, odborného vědeckého vedení (správce), nemá školených sil pro konservaci (laboranta) a síly kancelářské a dozorčí sotva stačí na řádný dohled v poměrně rozsáhlých sbírkách (umístěných v 22 síních ve 2 budovách o 3 traktech). V celku je v Národopisném museu českoslovanském zaměstnáno: 1 kustodka, 1 síla kancelářská (sekretáŕka), 2 písařky, které však spolu pomáhají při dozoru, 2 dozorci, kteří obstarávají čistění a úklid místností a, pokud stačí, konservaci památek, a 1 sluha (pro posilky apod.). Náklad osobní na uvedené síly je již dnes as Kč 70 000,-. Není však pochyby, že náklad ten ještě dále nevyhnutelně stoupne, nebot platy personálu nedají se držeti na dosavadní výši (pohybují se mezi Kč 450,- až 1 100,- Kč měsíčně). Proti tomu př́ijem, s nímž může Společnost Národopisného musea českoslovanského počítati, je Kč 60 000,-, nejvýše 72 000,- ročně. Poněvadž věcné náklady dostupují i při úplném omezení musejní činnosti při nejmenším Kč 35 000,- ročně, poněvadž pak museum by nemohlo býti trvale bez vedoucí síly úřední, je nutno počítati s ročním schodkem as 50 až 60 tisíc. Při tom, že jmění musejní 1. ledna 1921 bylo Kč 873 000,85, ocitlo by se Národopisné museum českoslovanské za rok, za 2 léta beze všech vlastních finančních prostředků. 
Letošním deficitem je opět již nyní jmění musejní asi o 35 000,- Kč ztenčeno. Nezbývalo by mu, poněvadž běžné př́ijmy nestačí na úhradu udržovacích nákladů, než-li likvidovat a snad docela musejní sbírky zavřít. Tomuto smutnému konci u ústavu, který byl u nás tak významný nejen v organisaci vědecké a lidově osvětné, nýbrž i v životě národně politickém, je třeba zabránit. Požadavek tento jistě plně odůvodňují již samy zásluhy Národopisného musea českoslovanského, jež prvé a své doby za starého Rakouska jediné dávalo instalací svých sbírek výraz národní jednotě Čechů se Slováky, které již v době předválečné v tomto směru působilo publikačně „Národopisnou mapou uherských Slovákư“ a „Národopisnou a dialektickou mapou zemí národa českoslovanského" a jež mělo odvahu ve směru tom působiti i za války, stačí tu vzpomenouti mravního významu, jejž mělo počátkem r. 1918 druhé vydání vzpomenuté „Národopisné a dialektické mapy“ i vydání prvého svazku „Národopisu lidu československého.“

Zachrániti Národopisné museum českoslovanské bylo by asi lze jedině převzetím jeho sbírek do majetku zemského a jejich přičleněním k národopisným sbírkám Národního musea v Praze. Společnost Národopisného musea českoslovanského odevzdala by za tím účelem bohaté své sbírky (mimo sbírky zemědělské retrospektivy) zemskému správnímu výboru beze vší náhrady pouze za splnění podmínek dále uvedených, jež by byly však jenom v zájmu další řádné a bezpečné jejich správy. Cena sbírek musejních je dnes jistě nad 5 milionů Kč. (Ač většina materiálu dostala se museu darem, přece jenom na pouhý nákup sbírek a knihovny Národopisné museum již vydalo Kč 83 810,40, na instalaci jejich Kč 63864,23 - a to v době, kdy ceny předmětů těch byly průměrem asi 20 kráte nižší cen dnešních). Ostatně památky uložené v Národopisném museu českoslovanském jsou tak cenné, vzácné, namnoze opravdu jedinečné, že je nelze podle běžných den trhu starožitnického ani odhadovati. Mimo to jistě nelze přehlížeti velký význam toho, že přičleněním materiálu Národopisného musea ke sbírkám Národního musea učiněn by byl první rozhodný krok k účelnému, jednotnému a organickému uspořádání a sloučení roztřišsěných ústředních musejních sbírek pražských, o nichž uvažují a píší odborné kruhy již bezmála po 2 desítiletí. Do programu Národního musea sbírky Národopisného musea českoslovanského přirozeně zapadají: mát Národní museum rovněž cenné sbírky národopisné, jejichž sloučením by bylo vytvořeno pravdu imposantní, bohaté a vědecky cenné národopisné oddělení Národního musea. Umístiti všechny národopisné sbírky ty bylo by možno při účelné instalaci v místnostech dosavadního Národopisného musea, čímž by se Národnímu museu uvolnily síně, potřebné pro oddělení jiná. Rozřešena by tím byla i otázka vědecké správy Národopisného musea: nebot' národopisné sbírky Národního musea mají svoji vědeckou správu, které by se prostě přidělily i sbírky nově připojení. Nemá proto rada Společnosti Národopisného musea českoslovanského pochyby, že výbor Národního musea i ministerstvo školství a národní osvěty by připojení sbírek jenom uvítaly. 
Náklad udržovací, o nějž by se zvýšily výdaje země na Národní museum následkem připojení sbírek Národopisného musea, nebyl by nad míru značný. Dostoupil by snad asi Kč 120 000,- až 150 000,- (viz připojený rozpočet), z nichž by však asi 50 000,- bylo uhrazeno subvencemi dosud poskytovanými Národopisnému museu.

Rada Společnosti NMČ proto doufá, že zemský správní výbor neodepře převzíti rokem 1922 do majetku zemského sbírky Národopisného musea českoslovanského (kromě sbírek Zemědělské retrospektivy), jejich instalační zařízení, knihovnu, archiv listin a archiv fotografický, jež by mu Společnost odevzdala beze vší náhrady pouze za podmínek:

1. že sbírky ty budou přičleněny k národopisným sbírkám Národního musea;

2. že zůstanou, pokud nebudou získány místnosti vhodnější, uloženy v dosavadních místnostech Národopisného musea na Smíchově č. p. 98 v zahradě Kinských, najatých od měst Prahy a Smíchova. Nájmu místností těch se za tím účelem Společnost NMČ vzdá za podmínky, že budou městem Prahou a Smíchovem k stejnému účelu nadále pronajaty zemskému správnímu výboru;

3. ̌e zemský správní výbor převezme do svých služeb dosavadní personál Národopisného musea a započte mu podle možnosti všechna léta, nebo aspoň přiměřenou část doby, dosud ztrávené ve službách musejních;

4. že v budově dosvade užívané Národopisným museem ponechá Společnosti NMČ jednu místnost pro kancelář a jednu pro sklad publikací a pověří některou z dosavadních sil Národopisného musea na dále konáním kancelářských prací Společnosti;

5. že knihovna Národopisného musea zůstane jako příruční knihovna při národopisných sbírkách, což ovšem nevylučuje, aby knihy, jež nejsou obsahu národopisného, nebyly z ní vyloučeny a zařazeny do knihovny Národního musea;

6. ̌e Společnost NMČ (Národopisná Společnost českoslovanská) bude nadále působiti a provozovati nejen činnost publikační, nýbrž i sběratelskou, jejíž výtěžky (mimo památky zemědělské retrospektivy) by odevzdávala do majetku země, aby byly uloženy v národopisných sbírkách Národního musea; že členům Společnosti té bude dovoleno bezplatně užívati k vědeckým účelům materiálu zjm. fotografického a knihovního národopisného oddělení Národního musea za kautel, jež by správa musea toho určila.

Očekáváme při tom, že zemský správní výbor při příštím jmenování zemských zástupců do výboru Společnosti Národního musea vezme přiměřený ohled na osoby, které by mu své doby navrhla rada Společnosti NMČ a umožní tak, aby dosavadní pracovníci Národopisného musea českoslovanského i nadále přímo spolupůsobili pro rozvoj a při správě sbírek, nashromážděných Národopisným museem českoslovanským. 
Spolu kdyby zemský správní výbor si přál pozměnění některých podmínek, vyslovujeme ochotu o event. změně jejich jednati.

Nadějíce se, že zemský správní výbor vyhoví žádosti rady Společnosti NMČ a přijme r. 1922 od ní do majetku zemského sbírky Národopisného musea českoslovanského a tím zachrání je bezpečně české veřejnosti pro všechnu budoucnost, píšeme se v dokonalé úctě

Předseda Dr. J. Jakubec m.p.

Za jednatele Dr. J. Matiegka, m.p.

\section{Příloha 2}

1. Smluvní strany shodují se v tom, že rozvoji československého národopisu bude na prospěch, dojdou-li snahy jejich pokud možno těsné součinnosti.

2. Za tím účelem provedou smluvní strany soustředění národopisných sbírek tak, že zemský správní výbor sbírky zemské a Společnost Národního Musea sbírky své a jí svěřená deposita, tudíž dosavadní národopisné oddělení Národního Musea v zahradě Kinských na Smíchově včetně odborné knihovny a ostatních pomůcek přestěhují a uloží společně s národopisnými sbírkami Československého zemědělského musea do nové budovy, kterou Československé zemědělské museum v Praze postaví.

3. Československé zemědělské museum poskytne pro sbírky dosavadního národopisného oddělení Národního Musea potřebné místnosti výstavní, místnosti pro odbornou knihovnu, místnosti správní a laboratoře k trvalému užívání a to v takovém rozsahu, jenž by plně vyhovoval všenárodnímu významu a potřebám jejich. Závazek tento bude zemi české i Společnosti Národního Musea na budově knihovně zajištěn.

4. Veškerý náklad spojený se správou a udržováním nové budovy musejní, dále veškerý náklad na otop a světlo, veřejné dávky atd. bude hraditi Československé zemědělské museum.

5. Československé zemědělské museum bude dále hraditi náklad, jehož jest třeba na udržování a systematické doplňování všech sdružených národopisných sbírek. Předměty z jeho prostředků zakoupené budou jeho vlastnictvím.

6. Na novou budovu musejní Československé zemědělské museum umístí na vhodném místě nápis, vyznačující, že v budově jsou umístěny též sbírky národopisného oddělení Národního Musea.

7. Inventáře všech národopisných sbírek budou nadále vedeny dosavadním způsobem tak, aby vlastnictví země České, Národního Musea, Československého zemědělského musea a deponentů zůstalo v trvalé patrnosti. 
8. Československé zemědělské museum se zavazuje, že změní čl. 22 svých stanov v ten smysl, že v př́padě zániku spolku připadnou veškeré jeho národopisné sbírky Národnímu Museu v Praze.

9. Odbornou správu sbírek bude vykonávati za pomoci personálu v čl. 10 uvedeného, zvláštní komise, v níž budou smluvní strany zastoupeny po dvou členech. Záležitosti správní bude vyřizovati a usnesení komise prováděti Československé zemědělské museum. Jednací řád si ustanoví komise sama se schválením zemského správního výboru.

10. Služební povinnosti dosavadního personálu národopisného oddělení Národního Musea rozšiřují se též na národopisné sbírky, kterých Československé zemědělské museum samo získalo aneb v budoucnosti získá a se sbírkami v čl. 2 uvedenými společně vystaví neb uloží. Bližší instrukce v tom směru vydá zemský správní výbor po dohodě se správou Národního Musea a Československým zemědělským museem. Právní poměr tohoto zaměstnanectva k zemi České zůstane nedotčen, rovněž i závazek země České personál ten na náklad zemského fondu dle potřeby za dosavadních podmínek rozmnožovati. Bezprostředním služebním přednostou tohoto personálu bude Československé zemědělské museum.

11. Dosavadní budova národopisného oddělení v zahradě Kinských na Smíchově čp. 98, zůstane po odstěhování národopisných sbírek Národnímu Museu zachována jeho účelům (k eventuelnímu umístění divadelního musea) za dosavadních podmínek. Stejně tak bude poskytnuta k užívání Národnímu Museu nynější budova, v níž uloženy jsou sbírky Československého zemědělského musea, čp. 97 v zahradě Kinských.

12. Tato smlouva nabývá platnosti schválením statutárních orgánů smluvních stran a to i když se tak stane dříve, nežli bude možno přemístění dle čl. 2 . provésti. Náklad na budovu (tj. na dosavadní budovu v zahradě Kinských čp. 98), zmíněný ve čl. 4., bude i nadále hraditi země Česká.

13. Aby pak pro budoucnost veliké sbírky musejní zůstaly v místní souvislosti, zemský správní výbor bude míti péči o to, aby pro př́rodovědecké oddělení Národního musea opatřeny byly pozemky, sousedící s pozemky budovy Československého zemědělského musea, pokud jejich poloha by byla pro novostavbu druhé budovy Národního Musea výhodnou.

14. Obsah čl. 1-12 této smlouvy jest potud jednotný, že v celém rozsahu pozbudou všechny platnosti, pokud by kterákoliv z nich z příčiny jakékoliv platnosti nedošel. 


\section{Prameny}

Archiv Národního muzea, fond Národní muzeum (1818-1960)

Archiv Národního muzea, fond RNM-HM4 - Národopisné oddělení (1826-2000)

Archiv Národního muzea, fond RNM - Společnost Národního muzea (1854-1993)

Archiv Národního muzea, fond Stránská Drahomíra (1899-1964)

\section{Literatura}

Altman, Karel. 2005. Česká etnografie a folkloristika na Moravě: od průkopníků k národopisnému hnutí (1800-1918). In Tyllner, Lubomír, Uherek, Zdeněk (eds.). Kultura - společnost - tradice I. Praha: Etnologický ústav AV ČR, 2005, s. 183-206.

Brouček, Stanislav. 1979. České národopisné hnutí na konci 19. století. Praha: Ústav pro etnografii a folkloristiku ČSAV, 1979.

Burian, Miroslav. 1968. Historické vědy v Národním muzeu. In Burian, Miroslav - Špét, Jiří (red.). Sto padesát let Národního muzea. Sborník příspěvků k jeho významu a dějinám. Praha: Národní muzeum.

Ducháček, Milan. 2016. Deset tezí k (dis)kontinuitě československé etnografie před rokem 1945. In Woitsch, Jiří - Jůnová Macková, Adéla a kol. Etnologie v zúženém prostoru. Praha: Etnologický ústav AV ČR, 2016: 37-67.

Ducháček, Milan. 2017. „Kufříkový profesor“ průkopníkem terénního výzkumu. Etnograf Karel Chotek na Univerzitě Komenského. In: 95 rokov Filozofickej fakulty UK. Pohlad do dejín inštitúcie a jej akademickej obce. Bratislava: Univerzita Komenského, 2017: 185-202.

Fabian, Václav. 1925. Fotografický archiv. In: Úkoly a cíle národopisu československého. Praha: 1925, s. 27-32.

Fabian, Václav. 1930. Malovaný nábytek lidový v Československu. Národopisný věstník českoslovanský 23: 122-128.

Horák, Jiří. 1933. Národopis československý. Přehledný nástin. In: Československá vlastivěda, II. Člověk. Praha: Sfinx - Bohumil Janda: 305-472.

Hrdá, Judita. 1999. Drahomíra Stránská (1899-1964). Bibliografická příloha Národopisné revue č. 13. Strážnice: Ústav lidové kultury.

Jungbauer, Gustav. 1937. Německý národopis v ČSR. In: Horák, Jiří Chotek, Karel - Matiegka, Jindřich (ed.). Československá vlastivěda. Řada II. - Národopis. Praha: Sfinx, 1937: 341-378.

Langhammerová, Jiřina. 2015. Příběh Musaionu - Expozice českého národopisu na půdě Národního muzea v průběhu času. Sborník Národního muzea - řada A 69: 5-14.

Lidová kultura. 2007. Národopisná encyklopedie Čech, Moravy a Slezska. Praha: Mladá fronta 2007.

Lozoviuk, Petr. 2006. Dějiny německy psaného národopisu v Čechách. In: Kultura - společnost - tradice II, Praha: Etnologický ústav AV ČR 2006: 13-51.

Lozoviuk, Petr. 2008. Interethnik im Wissenschaftsprozess. Deutschsprachige Volkskunde in Böhmen und ihre gesellschaftlichen Auswirkungen. Leipzig: Leipziger Universitätsverlag, 2008.

Mevaldová, Helena - Tauberová, Monika. 2011. Drahomíra Stránská. Osobnost evropské etnografie. Praha: Národní muzeum.

Mevaldová, Helena. 2015. Záměr vytvoření Muzea lidové architektury v prírodě v Praze. Sborník Národního muzea - řada A 69: 29-44.

Průvodce sbírkami Národního musea v Praze. II. Sbírky národopisné. Praha: Národní muzeum 1932. 
Saturník, Theodor. 1924. Národní museum za války a po válce. Praha: Národní museum.

Sklenář, Karel. 2001. Obraz vlasti: příběh Národního muzea. Praha: Paseka.

Sklenář, Karel. 2007. Společnost Národního muzea v dějinách i v současnosti. Praha: Národní muzeum.

Sklenář, Karel. 2014. Pravěká a raně středověká archeologie v dějinách Národního muzea, Fontes archeologici pragenses 40. Praha: Národní muzeum.

Smrčka, Vít. 2011. Dějiny České národopisné společnosti, čili, Dějiny psané národopisem. Praha: Česká národopisná společnost.

Steinová, Šárka. 2013. Osudový příběh Československého zemědělského muzea: (1891) 1918-1952. Praha: Národní zemědělské muzeum.

Stránská, Drahomíra. 1938. Národopisné museum v prírodě v Praze. s.I.

Stránská, Drahomíra. 1949. Národopisné oddělení. In: Skalský Gustav (red.). Národní museum 1818-1948. Praha: Národní muzeum, s. 119-136.

Šenfeldová, Helena. 2015. Starosti s umístěním bohatých sbírek nového Národopisného musea českoslovanského v roce 1896. Sborník Národního muzea - řada A 69: 15-20.

Švehla, Jaroslav. 1946. Bomby kolem Pantheonu. Národní museum $v$ letech 1938-1945. Praha: Národní muzeum.

Tyllner, Lubomír - Suchomelová, Marcela - Thořová, Věra. 2005. Etnologický ústav Akademie věd České republiky 1905-2005. Praha: Etnologický ústav AV ČR.

Woitsch, Jiří - Jůnová Macková, Adéla. 2016. Etnologie v zúženém prostoru. Praha: Etnologický ústav Akademie věd České republiky, v. v. i. 